NBER WORKING PAPER SERIES

\title{
THE DISTRIBUTION OF CRISIS CREDIT: EFFECTS ON FIRM INDEBTEDNESS AND AGGREGATE RISK
}

\author{
Federico Huneeus \\ Joseph P. Kaboski \\ Mauricio Larrain \\ Sergio L. Schmukler \\ Mario Vera \\ Working Paper 29774 \\ http://www.nber.org/papers/w29774 \\ NATIONAL BUREAU OF ECONOMIC RESEARCH \\ 1050 Massachusetts Avenue \\ Cambridge, MA 02138
}

February 2022, Revised March 2023

We thank participants at presentations held at the ASSA Annual Meetings, Chile's Central Bank, Financial Market Commission, and Ministry of Finance, the Federal Reserve Bank of Atlanta, the IMF Jacques Polak Annual Research Conference, the Inter-American Development Bank, the International Centre for Economic Analysis, the LACEA-LAMES Annual Meetings, the Middle East and North Africa Central Bank Conference, the MoFiR Workshop at Bank of Portugal, the SED Annual Meetings, and the World Bank for helpful comments. We also thank feedback from Rodrigo Alfaro, Mehdi Bartal, Solange Berstein, Felipe Córdova, Natalie Cox, Giovanni Dell'Arricia, Andrés Fernández, Aart Kraay, Patricio Toro, Camilo Vio, and Jasmine Xiao. We are grateful to Brian Castro, Esteban Espinoza, Joaquín Fernández, Regina Mannino, Pablo Muñoz, and especially Carolina Wiegand for outstanding research assistance. We thank Antonn Park for able editorial support. The World Bank Chile Research and Development Center, the Knowledge for Change Program (KCP), the Research Support Budget (RSB), and the UK's Structural Transformation and Economic Growth (STEG) research programme through Notre Dame's BIG Lab provided financial support for this paper. The findings, interpretations, and conclusions are those of the authors and do not necessarily represent those of the Central Bank of Chile, the Financial Market Commission of Chile, or the World Bank, its executive directors, the governments they represent, or the National Bureau of Economic Research.

At least one co-author has disclosed additional relationships of potential relevance for this research. Further information is available online at http://www.nber.org/papers/w29774

NBER working papers are circulated for discussion and comment purposes. They have not been peer-reviewed or been subject to the review by the NBER Board of Directors that accompanies official NBER publications.

(C) 2022 by Federico Huneeus, Joseph P. Kaboski, Mauricio Larrain, Sergio L. Schmukler, and Mario Vera. All rights reserved. Short sections of text, not to exceed two paragraphs, may be quoted without explicit permission provided that full credit, including (C) notice, is given to the source. 
The Distribution of Crisis Credit: Effects on Firm Indebtedness and Aggregate Risk

Federico Huneeus, Joseph P. Kaboski, Mauricio Larrain, Sergio L. Schmukler, and Mario

Vera

NBER Working Paper No. 29774

February 2022, Revised March 2023

JEL No. E44,E5,G01

\begin{abstract}
We study the distribution of credit during crisis times and its impact on leverage and risk at the firm and macroeconomic levels. We analyze a large-scale COVID-19 public credit guarantee program in Chile, using novel transaction-level credit data matched with tax data. We find that demand drives the increase in leverage, especially for riskier firms, but several factors keep aggregate risk small. Aggregate risk increases substantially when credit limits are relaxed, but reallocating the existing program credit toward riskier firms or raising the expected default increases risk much less. A quantitative model of firms and endogenous default confirms our empirics.

Federico Huneeus

1180 Agustinas

Office 352B

Research Department (DIE)

Central Bank of Chile

Santiago, RM 8340454

Chile

fhuneeus@bcentral.cl

Joseph P. Kaboski

Department of Economics

University of Notre Dame

3039 Nanovic Hall

Notre Dame, IN 46556

and NBER

jkaboski@nd.edu

Mauricio Larrain

Catholic University of Chile

School of Management

Avenida Vicuña Mackenna 4860

Santiago

Chile

mauriciolarraine@gmail.com

Sergio L. Schmukler

The World Bank

MSN MC3-301

1818 H Street, N.W.

Washington, DC 20433

Sschmukler@worldbank.org

Mario Vera

Financial Market Commission of Chile

Av. Libertador Bernardo O'Higgins 1449

Santiago 834-0518

Chile

mavera@cmfchile.cl
\end{abstract}




\section{Introduction}

During economic crises, governments often try to help struggling firms survive and recover more quickly by providing financing. In doing so, they must balance the need to quickly reach broad coverage across firms with the tradeoff of potentially distributing untargeted assistance to firms that do not need help or are too risky. As a result, they might increase the overall indebtedness of the private sector, leading to aggregate risk, financial instability, and fiscal costs going forward.

We study the aggregate consequences and risks of government-induced credit injections during crises, or "crisis credit." These consequences and risks hinge critically on how debt is actually distributed across different types of firms. We analyze the allocation of a large-scale public credit guarantee program (henceforth credit program) implemented in Chile during the COVID-19 pandemic that grants credit for $4.6 \%$ of gross domestic product (GDP). We collect transaction-level information on the universe of bank credit to all firms, including loan applications from firms and approvals and rejections from banks. We match the financial data with administrative tax data for the universe of formal firms. We use these unique micro data to study how the firm credit distribution aggregates up into macroeconomic outcomes.

Our main result shows that there is a sharp distinction between the micro and macro effects of these types of programs. At the micro level, there is a large expansion of indebtedness both within firms and across firms with different risk profiles. Consistent with the literature that finds negative or adverse selection, the credit expansion is characterized by a shift in lending toward riskier firms, which is observed on both the extensive margin (selection into the program) and the intensive margin (increases in debt and leverage). ${ }^{1}$ Nevertheless, our results show that macro risk remains small. This holds not only for the actual program but under a variety of alternative scenarios (though not all) and regardless of whether we use ex-ante expected default rates or the ex-post realization of default.

We identify several mitigating factors that contribute to the low macro risk. A first group of factors is related to the policy design. In particular, the policy establishes caps on the amount of credit at the firm level depending on its sales. It also imposes an interest rate ceiling, which effectively excludes the riskiest firms in the economy, even when the program targets small- and medium-sized enterprises (SMEs). The policy also excludes firms with

\footnotetext{
${ }^{1}$ We use the term "adverse selection" in a loose sense to convey credit going to riskier clients. Unlike the literature that presumes asymmetric information, our empirical estimations are based on observable information, and the model we present has symmetric information.
} 
previous default. ${ }^{2}$ In addition, the guarantee is only partial, so banks have skin in the game and thus have incentives to screen firms.

A second group of mitigating factors is related to the equilibrium behavior. In practice, most credit flows toward large and safe borrowers. Even when their debt increases the least in proportional terms, their sheer ex-ante size makes them large recipients of the actual volume of new loans. Furthermore, there is a low ex-ante and ex-post aggregate default risk in general. ${ }^{3}$

We evaluate the importance of different mitigating factors in keeping aggregate risk low using both empirical and model-based counterfactuals. Empirically, by computing the credit allocation to formal firms with different risk profiles, we calculate an expected aggregate default (expected loss) of $0.27 \%$ of GDP for the baseline scenario. We then assess alternative scenarios that would affect the distribution of credit across risk groups by mechanically changing the credit allocations or risk levels of different groups. Increasing the expected default rates of safer groups or reallocating the credit granted toward firms in the riskiest category raises the expected loss up to $0.65 \%$ of GDP. To obtain an aggregate risk of the program credit higher than $1 \%$ of GDP, one would need to substantially change the policy design. The policy features that matter the most are the cap on the loan amount per firm (enabling the riskiest firms to borrow more) and a transfer of all risk from banks to the government (therefore eliminating banks' incentives to screen). The risk transfer alone raises the expected loss to $0.77 \%$ of GDP. However, the combination of less incentives for banks and a relaxation of the credit cap raises the overall volume of loans and the allocation toward riskier firms, pushing the expected loss to $1.95 \%$ of GDP. In sum, factors related to the existing environment appear less important for aggregate risk than policy design factors that limit the allocation of credit, especially to the riskiest firms.

Complementing the empirical analysis, we develop a simple model of default in competitive financial markets that incorporates the endogenous responses of firms and banks. We model static loans to firms that vary in their revenue productivity, equity, and risk. The model confirms quantitatively the empirical results that a wide range of firms increase

${ }^{2}$ The policy in Chile has similarities with other public credit guarantee programs, such as those in Colombia, Italy, and the United Kingdom (OECD, 2017). It is also related to an array of credit programs in more than 142 countries applied during the COVID-19 pandemic (Feyen et al., 2021). Compared to the well-known U.S. Paycheck Protection Program, the quantity of credit extended is up to three months of the firms' sales in Chile (versus 2.5 months of payroll costs in the United States) and the interest rate is capped at a low level of $3.5 \%$ in Chile (versus $1 \%$ in the United States).

${ }^{3}$ There is another factor involving the banking industry. The solvency of banks increases because of both a capitalization incentivized by regulation and also a reduction of risk-weighted assets, given the guarantees of the policy. Although this is an equilibrium effect of the policy that reduces aggregate risk, we do not focus on the risk of the banking sector. 
indebtedness, yet little credit flows to the riskiest firms under the government policy, and aggregate risk is small. Theoretical counterfactual simulations confirm that aggregate risk remains small under a variety of policies, even when the demand for credit is endogenous to these policies. Indeed, given partial repayment upon default, actual losses are smaller than projections of at risk credit in our empirical exercises. Moreover, the model demonstrates that the interest rate cap of the policy plays a role similar to the credit limits that the empirical exercise uncovers: the low interest rate cap lowers bank profitability on loans to risky firms, limiting the amount of credit lent to the riskiest firms. To substantially increase aggregate risk given the lending volumes, the model suggests that a sizeable negative aggregate shock would be needed.

The lessons from this paper are likely to be important beyond Chile and could be informative for credit policy responses to future crises. Our findings on the distribution of credit do not seem to be driven by the pandemic effects on firm performance. First, firms with both positive and negative variations in sales during the pandemic are more likely to apply and be approved for credit than other firms. Second, there is no difference in credit distribution to firms in municipalities under lockdown and those in contiguous municipalities with free circulation. Third, the broad adoption of the credit program regardless of the pandemic impact is particular to the credit program. In contrast, a simultaneous large employment program, which imposes an opportunity cost for firms to use it, does not lead to such broad uptake. We find that firms that apply for the employment program are seemingly more impacted by the pandemic and are not ex-ante riskier, and lockdowns play a special role in the demand for the employment program. Furthermore, the conclusion that aggregate risk stays small despite adverse selection at the micro level holds under a wide range of alternative policy ingredients and environment factors.

The rest of the paper is organized as follows. Section 2 connects our paper with the literature. Section 3 presents the data. Section 4 describes the case we study. Section 5 shows the distribution of credit across firms. Section 6 studies the effects on firm-level indebtedness. Section 7 analyzes the aggregate implications. Section 8 presents the model. Section 9 concludes.

\section{Contribution to the Literature}

A large and growing literature studies the consequences of government-induced credit at any time and the allocation of credit to firms during crisis times. Part of this literature focuses 
on government assistance to a particular segment of firms, SMEs, provided through credit lines backed by public guarantees or through public banks. ${ }^{4}$ A key concern highlighted in this literature, as discussed in Jiménez et al. (2018), is adverse selection. ${ }^{5}$ We add to this literature by examining an economy-wide government credit program with a wide set of lenders and firms. We confirm earlier studies that such programs suffer from adverse selection but we also show that the high indebtedness by risky firms can happen at a much wider scale, when credit is offered to most firms by all types of banks (not just public ones). Using our comprehensive data on loan applications and bank responses, we also show that demand can drive this adverse selection and that the supply side can play a role in mitigating this effect.

With the COVID-19 pandemic, the interest in government programs to help channel credit to firms has grown significantly. ${ }^{6}$ A notable example is the Paycheck Protection Program (PPP) in the United States. ${ }^{7}$ A key discussion in this literature is whether loans go to all firms or to the largest ones that could more easily take advantage of government programs, something documented for the PPP. However, the evidence tends to be based on syndicated loans targeted to large firms or on a sample of all the corporate loans. A primary example is Chodorow-Reich et al. (2021), who merge PPP information with supervisory data on loans greater than US $\$ 1$ million from banks with assets over US $\$ 100$ billion. Using data on all firms and loans, we show that the program we study rapidly and effectively reaches a broad set of firms with both large and small firms increasing leverage. Thus, even when a significant fraction of the credit goes to large firms, proper incentives can generate bank lending to a wide set of firms with varying size and risk profiles.

Last, but most importantly, we contribute to the literature addressing the macrolevel consequences of micro-level decisions regarding debt accumulation, as high aggregate debt can generate macroeconomic problems and financial distress (Reinhart, 2022). Public programs can reduce bankruptcies and firm failures (Carletti et al., 2020; Demmou et al., 2020; Cros et al., 2021; Díez et al., 2021; Gourinchas et al., 2021). But high debt accumulated

\footnotetext{
${ }^{4}$ See, for example, Smith (1983), Gale (1990), Gale (1991), Lelarge et al. (2010), Brown and Earle (2017), de Blasio et al. (2018), Jiménez et al. (2018), Mullins and Toro (2018), Barrot et al. (2021), Akcigit et al. (2021), Bachas et al. (2021), and Gonzalez-Uribe and Wang (2021).

${ }^{5}$ Complementing the credit assistance programs, employment programs can also lessen large debt buildups, the payroll burden, and layoffs that could further impair economic activity during and after crises (Hijzen and Venn, 2011; Cahuc et al., 2018, 2021; Giupponi and Landais, 2018; Kopp and Siegenthaler, 2021).

${ }^{6}$ See, for example, Amiram and Rabetti (2020), Bennedsen et al. (2020), Keller and Zoller-Rydzek (2020), Balyuk et al. (2021), Core and De Marco (2021), Custodio et al. (2021), Duchin et al. (2021), and Li and Strahan (2021). Comprehensive recounts of the programs used are compiled, among others, by Harvard's Kennedy School, the IMF, and Cirera et al. (2021).

${ }^{7}$ See, for example, Acharya and Steffen (2020), Bartik et al. (2020), Chetty et al. (2020), Granja et al. (2020), Hubbard and Strain (2020), Li et al. (2020), Chodorow-Reich et al. (2021), Greenwald et al. (2021), and Autor et al. (2022).
} 
during crises can also lead to the emergence of zombie firms, low investment, and debt overhang (Caballero et al., 2008; Schivardi et al., 2017; Kalemli-Ozcan et al., 2019; Xiao, 2020; Chari et al., 2021), especially when governments are involved (Banerjee and Hofmann, 2020; Brunnermeier and Krishnamurthy, 2020; Cevik and Miryugin, 2020; Demmou et al., 2021; Reinhart, 2022). Our comprehensive data allow us to connect the micro and macro implications and show that distributing credit broadly to firms that demand it, even when characterized by adverse selection, need not necessarily lead to aggregate government or banking sector risks. Our secondary analyses examining pandemic sales changes, lockdowns, and the concurrent employment program demonstrate that such findings are likely relevant beyond the pandemic. Our data counterfactuals (using separate information on loan applications and loans granted) and our model counterfactuals show the relevance of our results beyond the particulars of the Chilean economy and policy. The detailed connection between the micro evidence and the macro implications is the main contribution of our paper.

\section{Data}

We use three administrative data sets from various sources in Chile. These data sets cover the entire formal private sector in Chile in rich detail, including credit flows and balances, default history, and terms of the individual transactions. The firm-level data contain financial statements, input use, and sales collected monthly, plus industry and location of firms. Below we describe the data sources, sample selection, and key variables.

First, we use granular confidential bank-to-firm information compiled by the Financial Market Commission (the financial supervisory agency) for all firms using the entire banking system. We have information on stocks and flows of credit. For stocks, we have data on the amount of debt each firm has with each bank in the system every month. We also know the number of days each loan in the system is past due. For flows, we have transaction-level data on each loan received by each firm, including information on the loan amount, interest rate, and loan maturity. We complement the bank data with unique data on the credit program we analyze, including detailed information on loan applications by firms (such as the amount requested) as well as banks' decisions (such as whether a loan request is approved or rejected and the approved amount). These data allow us to measure selection and to disentangle supply and demand factors in the allocation of credit across the whole economy.

Second, we use confidential administrative tax records from Chile's tax authority (Servicio de Impuestos Internos). These data contain monthly, firm-level information including 
sales, materials expenditure, value added, number of workers, wage bill, net worth, age, industry, and municipality. They allow us to construct measures of pre-pandemic firm attributes (such as productivity, measured as value added per worker) as well as firm performance during the pandemic, using monthly sales during 2020 .

Third, we work with publicly available firm-level data on firms that use the employment program, a policy of interest for comparison purposes. These data are published monthly by the employment authority (Dirección del Trabajo) and contain the dates that each firm uses the employment program and the number of workers in each firm that participates in the program.

We merge these data sets using unique tax identifications (IDs) of workers and firms that are common across sources. To secure the privacy of workers and firms, the Chilean tax authorities require all published results to be calculated using at least 25 unique tax IDs. We conducted all the analysis accordingly and did not involve nor compromise the Chilean authorities. Officials from the Central Bank of Chile processed the disaggregated tax records and merged them with financial records from the Financial Market Commission. ${ }^{8}$ The merged data set allows us to study real and financial aspects of both the credit and the employment program covering the universe of firms. For most of the analysis, we use the 2018-2020 period of these data sets.

We utilize several samples of the merged data that we use in different parts of the paper, each with a different size and coverage (as shown in Online Appendix Table A1). To construct the samples of firms we use, we start from all legal and formally registered firms in the economy $(602,874$ firms $)$ that have a tax ID, which we call formal firms. ${ }^{9}$ The first sample, which we call active firms, is constrained to include only firms with positive sales in 2019, which amounts to 449,615 firms. We use this sample to conduct the aggregate analysis of the paper and the mapping between micro and macro patterns. This sample represents $75 \%$ of firms, $92 \%$ of employment, $82 \%$ of the stock of credit, and $100 \%$ of positive value

\footnotetext{
${ }^{8}$ This study was developed within the scope of the research agenda conducted by the Central Bank of Chile $(\mathrm{CBC})$ in economic and financial affairs of its competence. The CBC has access to anonymized information from various public and private entities, by virtue of collaboration agreements signed with these institutions. To secure the privacy of workers and firms, the CBC mandates that the development, extraction and publication of the results should not allow the identification, directly or indirectly, of natural or legal persons. Officials of the Central Bank of Chile processed the disaggregated data. All the analysis was implemented by the authors and did not involve nor compromise Chile's tax authority, the CBC nor the Financial Market Commission. The information contained in the databases of the Chilean IRS is of a tax nature originating in self-declarations of taxpayers presented to the Service; therefore, the veracity of the data is not the responsibility of the Service. ${ }^{9}$ We exclude natural persons who use their personal tax ID to borrow as a firm. For these natural persons, we do not have the same scope of information as we do for active firms, and we exclude 818,572 tax IDs for this reason. These natural persons are only included in our aggregate analysis when we report the total value of the program and in our estimate for total expected credit loss (Table 6).
} 
added in the economy. Among active firms, $97 \%$ are SMEs and contribute $43 \%$ and $27 \%$ of total employment and credit in the economy, respectively. The remaining $3 \%$ of active firms are large firms $(2 \%)$ and mega firms $(1 \%)$.

The second sample is used to estimate the default probability models that measure firm-level default risk. Starting from the active firms sample, this second sample includes only firms with available data on default during 2019, plus sales, number of workers, value added, firm age, municipality, and industry in December 2018. Firms in default are those with loans past due 90 days. We consider only "banked" firms to estimate the model, i.e., firms that have outstanding debt as of December 2019 or receive a loan over the period 2012-2019. Otherwise, the firms are considered unbanked. Banked firms constitute $36 \%$ of active firms (capturing $79 \%$ and $87 \%$ of employment and value added, respectively).

The third sample adds further restrictions to the active firms sample. We restrict the sample to all firms with the relevant observables to perform the main regression analysis, which includes a measure of default risk. This sample excludes firms that use the employment program before the public credit guarantee program starts (end of April 2020) to make a more equal comparison between the two policies. We call this the selection and leverage model sample. This sample represents $18 \%$ of firms, $50 \%$ of employment, $44 \%$ of the stock of credit, and $74 \%$ of value added. Although this sample is smaller than the others, it provides detailed information at the firm level that is unavailable for other firms and is essential for the regression analysis we perform.

The fourth sample starts from the selection and leverage model sample and imposes the eligibility constraints from the public credit guarantee program, namely that firms must be smaller than the sales threshold imposed by law and cannot have payments past due more than 30 days (i.e., a strict measure of default). ${ }^{10}$ We call this the credit program eligible firms sample. This sample represents $17 \%$ of firms, $35 \%$ of employment, $21 \%$ of the stock of credit, and $19 \%$ of value added.

The fifth sample starts from the credit program eligible firms sample and selects only the firms that actually use the credit program. We call this the credit program users sample, but it actually constitutes only the subsample of firms with the required observable data (i.e., the selection and leverage model sample). This sample represents $6 \%$ of firms, $14 \%$ of employment, $9 \%$ of the stock of credit, and $7 \%$ of value added. ${ }^{11}$ For some estimations, we further partition different samples based on their banking status. In particular, we split the

\footnotetext{
${ }^{10}$ The employment program does not have a selection constraint at the firm level (other than having positive employment).

${ }^{11}$ Online Appendix Table A2 shows detailed summary statistics of the main variables used in our paper.
} 
selection and leverage model sample, credit program eligible firms sample, and the credit program users sample into two sub-samples of banked and unbanked firms.

Although the different samples have different coverage based on the data availability, we compute the aggregate effects for all firms. To do so, we use the default probability for each type of firms and aggregate the total effects using the total credit allocated to each group. We also impute the default probability of the high risk group to the firms with no risk data, such that we avoid underestimating aggregate risk.

\section{Government Programs and the Expansion of Crisis Credit}

The crisis credit episode we study originates with the COVID-19 pandemic. With the health system under severe stress due to the pandemic's early spread, the Chilean government imposes mandatory lockdowns in several municipalities across the country, starting in March 12, 2020. ${ }^{12}$ Many businesses are forced to close temporarily, either because their demand collapses or because of the impossibility of operating under lockdown. Firms' cash flows collapse. By November 2020, Chile is the country with the fourth most infections per million people in Latin America and the Caribbean (Engel et al., 2020), and the economy suffers a sizable 5.8\% GDP contraction in 2020 (down from a 0.9\% expansion in 2019).

In response to the crisis, the Chilean government implements large programs to help firms and to avoid inefficient bankruptcies. It first significantly expands the size and scope of an existing public credit guarantee program, providing financing to firms during the pandemic and sharing the firm credit risk with banks. The existing program, called FOGAPE, is a public fund that guarantees a fraction of loans provided by banks to small firms, those with annual sales less than US $\$ 0.8$ million. ${ }^{13}$ In the event of default, resources are withdrawn from the fund to pay the guaranteed fraction of the loan to the bank. The program has similarities with the other public credit guarantee programs used around the world.

On April 24, 2020, the National Congress of Chile approves a bill (called FOGAPE COVID-19) proposed by the Ministry of Finance that injects US $\$ 3$ billion into the public credit guarantee fund (1.2\% of Chile's GDP). The law also extends access to the program to medium, medium-large, and large firms. Medium firms have annual sales between US $\$ 0.8$ and US\$3.5 million, medium-large firms between US\$3.5 and US $\$ 21$ million, and large firms

\footnotetext{
${ }^{12}$ Chile is divided into 16 regions. Each region is divided into municipalities, which constitute the country's smallest administrative division. There are 345 municipalities in Chile.

${ }^{13}$ FOGAPE is an acronym for Fondo de Garantía para Pequeños Empresarios or Guarantee Fund for Small Entrepreneurs.
} 
between US $\$ 21$ and US $\$ 35$ million. ${ }^{14}$ Mega firms (those with annual sales above US $\$ 35$ million) remain ineligible for the program. This expanded credit program is the focus of our analysis.

Guaranteed loans are designed to finance working capital up to three months of sales, with monthly sales measured as the average for the pre-pandemic period (January to December 2019). The loans have a six-month grace period and are payable in installments during the proceeding 24 to 48 months. They have a low interest rate cap of 3.5\%, equal to the monetary policy rate $(0.5 \%)$ plus the inflation target $(3 \%)$. The cap is notably lower than statutory caps of $20 \%$ on other loans and implies a real interest rate close to $0 \%$. The program requires banks to restructure all of the firm's existing debts with the bank; the guaranteed loans cannot be used to repay prevailing obligations. Therefore, the program provides fresh resources to firms. Only firms that are up to date with their debt payments (no more than 30 days past due) at the moment of applying for the guaranteed loan are eligible for it.

After a firm applies for a guaranteed loan, the bank performs a risk analysis of the firm and can either accept or reject the application. The credit program is partial so that banks retain some "skin in the game," and thus it provides incentives to screen and monitor borrowers. The guarantee decreases with firm size: it is $85 \%, 80 \%, 70 \%$, and $60 \%$ for small, medium, medium-large, and large firms, respectively. To further align bank incentives, the guarantee is effective after applying a first-loss deductible of $5 \%$ for small firms, $3.5 \%$ for medium firms, and $2.5 \%$ for medium-large and large firms. As a result, for relatively high (low) default rates of the loan portfolio, the government (banks) absorbs most of the credit risk. That is, the program allows banks to transfer the tail credit risk to the government. ${ }^{15}$

In terms of reach, the credit program in Chile is fast and sizable. Banks provide the majority of the guaranteed loans in the first two months of the program, more than US $\$ 8$ billion or 3.3\% of GDP (Figure 1, Panel A). After five months (by September 2020), banks grant more than US $\$ 10$ billion in guaranteed loans (4.4\% of 2019 GDP). By the end of the year, the program's size reaches US $\$ 11$ billion (4.6\% of 2019 GDP). This is large relative to the employment program in Chile and the PPP in the United States (3.1\% of 2019 GDP

\footnotetext{
${ }^{14}$ In practice, the different sales limits are defined in Unidades de Fomento (UF), Chile's unit of account. We transform the values from UF to US dollars using the average value of UF in pesos during 2019 and the dollar-peso exchange rate during 2020. Banks could use different sales indicators to determine each firm's sales.

${ }^{15}$ Suppose, for example, that the ex-post default rate on a bank's loan portfolio to small firms (with a public guarantee of $85 \%$ ) is $12 \%$. Because of the deductible, the bank absorbs the first loss of $5 \%$. Of the remaining $7 \%$ loss, the bank absorbs $1 \%(=0.15 \times 7 \%)$ and the government the remaining $6 \%(=0.85 \times 7 \%)$. In total, the bank absorbs $6 \%$ of the credit loss. Because the deductible is fixed, as the ex-post default rate increases, the fraction of risk absorbed by the bank decreases. In an extreme default event, the government absorbs most of the credit risk.
} 
approved during 2020). It is also sizable compared to a total credit expansion of $4.7 \%$ of 2019 GDP during 2019 and a collapse during past crises. Through the increase in credit across firms, the credit program counteracts the 2020 contraction of net credit granted outside its purview (when GDP suffers a 5.8\% negative shock).

The employment program in Chile is the other major policy that helps firms during the crisis, but it presents a very different incentive structure than the credit program. On April 1, 2020, Congress approves the Employment Protection Act, enabling firms with government support to cover salaries and maintain firms' contracts with their workers while the employees are not working. The law allows distressed firms to freeze labor contracts with their employees rather than firing them. Workers' salaries are covered through withdrawals from the existing unemployment insurance fund, and the program alleviates firms' cash flows by reducing wage expenses. Like the credit program, the employment program expands on an existing program, a mandatory unemployment insurance program funded by three sources: workers, firms, and the government. ${ }^{16}$

Under the Employment Protection Act, the government injects US\$2 billion into the solidarity component of the unemployment insurance fund ( $0.8 \%$ of Chile's GDP). Firms can either apply for total employment protection or partial protection. In the latter case, firms and workers agree on a temporary reduction of the work schedule (up to 50\%). In comparison with the credit program, the key difference in incentives is that firms must shut down to qualify for the employment program so workers can stay home. The (opportunity) cost for a firm participating in the employment program is therefore the foregone output from the workers with frozen labor contracts. Both SMEs and large firms have access to the program by simply applying to it.

We plot the size of the employment program by calculating the value of the wage bill each firm saves from paying salaries to its workers with frozen labor contracts (Figure 1, Panel A). Then, we sum the wage bill savings across all firms participating in the employment program. The size of the employment program is nearly an order of magnitude smaller than the credit program. By December 2020, the employment program amounts to 0.8\% of GDP, meaning that the credit program is five times larger than the employment program.

Guaranteed loans overtake overall credit in the economy during 2020. Until the

\footnotetext{
${ }^{16}$ The insurance fund has an individual and solidarity component. Workers contribute a fraction $(0.6 \%)$ of their wages every month, which is deposited directly into their individual fund accounts. Firms contribute a fraction $(2.4 \%)$ of each worker's wage (two-thirds going to the individual account, and the rest to a solidarity fund). The government makes a variable yearly fiscal contribution to the solidarity fund. When a worker is fired for reasons attributable to the firm, they can withdraw from their individual account. Once the individual account is empty, the worker can withdraw from the solidarity fund.
} 
credit program starts, total credit in the economy is essentially equal to non-guaranteed credit (Figure 1, Panel C). After the government starts guaranteeing credit risk in May 2020, cumulative non-guaranteed credit starts decreasing while guaranteed credit increases significantly. Consistent with the findings for the United States (Acharya and Steffen, 2020; Chodorow-Reich et al., 2021; Greenwald et al., 2021), non-guaranteed credit to mega firms grows fast during the initial two months of the pandemic (Figure 1, Panel D). But three months after the pandemic starts, the loan growth rate to mega firms starts decreasing and credit instead flows to SMEs and large firms. In sum, year-to-year overall credit growth during 2020 is explained exclusively by guaranteed loans to smaller firms. This contrasts strikingly with the collapse in credit during the 1998 Asian crisis and the 2009 subprime crisis, when the public credit guarantee program in Chile was negligible (Didier et al., 2021).

A sizable share of firms (almost $25 \%$ of eligible firms) obtain guaranteed loans by December 2020, many of them previously "unbanked" (with no bank credit history). ${ }^{17}$ The adoption happens right in the program's first few months (Figure 1, Panel B). This constitutes a large take-up compared to other countries that implement similar public credit guarantee programs during the pandemic. For example, in Peru, Colombia, and Mexico, 14\%, 16\%, and $23 \%$ of eligible firms use the credit program, respectively. ${ }^{18}$ The low take-up is not restricted to developing countries; only $16 \%$ of firms use the 2020 public credit guarantee program in Italy (Core and De Marco, 2021). The employment program in Chile is smaller in value than the credit guarantee program, but it is also used by a significant fraction of firms, more than $16 \%$ of active firms by December 2020 (Figure 1, Panel B). Around 33\% of all active firms in the economy participate in either the credit or the employment program, and almost $7 \%$ of all firms participate in both programs.

In terms of applications, approvals, and usage within the active firms sample, 156,847 firms apply for credit guaranteed loans by December 2020, corresponding to $36 \%$ of all the eligible firms. Of all the loan applications, banks approve loans for 111,205 firms, indicating a high approval rate of $88 \% .{ }^{19}$ But not all firms that receive an approval end up using the program. In the estimations, we distinguish between approvals and usage to construct separate dummy indicators.

The credit program is used by banked and unbanked firms: $61 \%$ of the firms within the

\footnotetext{
${ }^{17}$ The $25 \%$ take-up is based on the active firms sample. The take-up is higher (35\%) when using the selection and leverage model sample.

${ }^{18}$ This information is obtained from reports by the Central Reserve Bank and the National Institute of Statistics and Informatics of Peru, the National Guarantee Fund of Colombia, and the government of Mexico. ${ }^{19}$ The approval rate is calculated over 126,524 firms that are not only eligible but also provide the correct paperwork to process the guaranteed loan application.
} 
active firms sample that receive a guaranteed loan are banked and $39 \%$ are unbanked. This indicates that the program has an important effect on financial inclusion, by providing bank credit to a significant number of firms with no previous bank debt. Banked and unbanked firms receive $92 \%$ and $8 \%$ of the total value of guaranteed credit, respectively. Regarding size, the program is allocated primarily to smaller firms: $96 \%$ of the firms using it are SMEs, and only $4 \%$ are larger firms. In comparison, $56 \%$ of the firms that use the employment program are banked firms and $96 \%$ are SMEs.

\section{Credit Distribution across Firms}

Having demonstrated that the credit program induces a large increase in aggregate credit, we now study the distribution of credit across firms with different risk.

\subsection{Measuring Firm Risk}

To assess a firm's ex-ante credit risk, we estimate a default probability model, which we then use in our selection models. We estimate the following cross-sectional probit model to predict default during 2019, based on attributes during 2018:

$$
\operatorname{Pr}\left(\text { Default }_{i}=1\right)=\Phi\left(\beta \text { Characteristics }_{i,-1}+\alpha_{s}+\alpha_{m}+u_{i}\right) .
$$

Default $_{i}$ is a dummy equal to one if the firm defaults on a loan during 2019 (i.e., has a loan past due more than 90 days) and is zero otherwise. Characteristics ${ }_{i,-1}$ is a vector of ex-ante firm-level attributes during 2018 that the literature uses to predict default rates (Glennon and Nigro, 2005; Crawford et al., 2018). ${ }^{20}$ This vector contains five real economic variables reported to the tax authorities: net worth, value added per worker (proxy for productivity), age, wage bill (proxy for labor intensity), and sales (proxy for size). It also includes two financial variables collected by the financial supervisory agency: credit stock and loan spread. The spread is the difference between the weighted average interest rate of the loans a firm received (using the loan amounts as weights) and the risk-free rate. We calculate this measure for the loans granted during 2012-2018 to use a longer time period. The spread reflects the ex-ante perception of risk by banks that grant the loans. We sequentially introduce industry and municipality fixed effects into the estimation.

Table 1 presents estimates of Equation (1) using different specifications. Columns 1-4 include the real regressors for those firms (these specifications are most useful since these variables are available for the largest set of firms and can therefore be used below to impute risk measures even for unbanked firms.) Firms that have a higher net worth and are more

\footnotetext{
${ }^{20}$ The results hold if we use firm-level data during 2016-2019.
} 
productive, older, more labor intensive, and smaller have a significantly lower likelihood of default. The results remain unchanged for different sets of fixed effects. Columns 5-8 add the financial regressors, which also have little impact on the coefficients of most of these real factors with one exception: after controlling for the debt level, larger firms (according to sales) are less likely to default ex-post. Controlling for real variables like net worth, firms with higher debt and ex-ante perceived to be riskier are also more likely to default ex-post. The results are robust to using different regressors and samples. ${ }^{21}$

To predict risk of default during 2020, we use this model and plug in the real and financial variables in 2019. For banked firms, we predict default risk using the estimated coefficients from Table 1, Column $8 .^{22}$ For unbanked firms, which by definition do not have financial information, we predict risk for 2020 using the estimated coefficients from Column 4, that is, plugging in the values of the real variables for 2019. The predicted default probability for unbanked firms is $10.7 \%$, roughly 2 percentage points higher than for banked firms. The risk measure for banked firms is more accurate than for unbanked firms because it is based on both real and financial data.

In the analysis, we use real and financial variables in 2019 to predict risk in 2020. The model does a good job at those predictions. In particular, unreported results show that the ex-post probability of default of the program credit between 2020 and 2022 is $1.29 \%$ for the firms with the lowest ex-ante risk and $3.69 \%$ for the firms with the highest ex-ante risk. That is, we find that there is a positive correlation between ex-ante and ex-post default risk. In addition, we find that the overall level of ex-post default risk is lower than the predicted default rate. The relatively low failure rates ex-post could be explained by the programs implemented during the crisis, as the literature argues. Importantly, these results suggest that the prediction model does not underestimate risk out of sample during the pandemic. Nor are artificially low ex-ante default estimates driving our aggregate outcome conclusions. Just in case, however, in the last empirical section of the paper we compute alternative counterfactual estimates using a higher default rate to gauge their impact.

\footnotetext{
${ }^{21}$ Among other things, we estimate the regression using the real regressors except net worth, a variable missing for $43 \%$ of the firms. We deal with this problem by using a dummy variable to indicate if the firm reports net worth or not. We also estimate the regression for the subset of firms that have both real and financial information. Furthermore, we use loan spread for the loans granted in 2012-2018 and for those granted only in 2018. We also include lagged default probability in the right-hand side of the regression. Last, we use the 2017-2018 sales variation as an additional control. The main results are robust to these extensions and are available in Online Appendix Table A3.

${ }^{22}$ This specification includes both industry and municipality fixed effects.
} 


\subsection{Selection into the Government Programs}

We next focus on the characteristics of the firms that participate in the credit program and contrast it with the selection into the employment program. We estimate the following cross-sectional probit model among the sample of firms that fulfill the eligibility requirements of each program:

$$
\begin{aligned}
\operatorname{Pr}\left(\text { ProgramUse }_{i}=1\right)= & \Phi\left(\beta \text { Risk }_{i}+\gamma \text { Sales Growth }_{i}\right. \\
& \left.+\psi \text { Other Program Use } e_{i}+\alpha_{s}+\alpha_{m}+u_{i}\right) .
\end{aligned}
$$

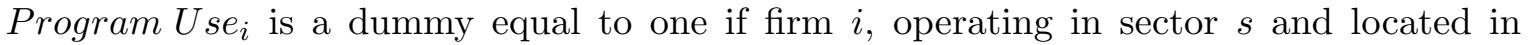
municipality $m$, participates in the given public program and is zero otherwise. The variable risk is estimated from the default probability model as explained above. To assess COVID-19's impact on the program, and knowing that the relation between credit expansion and sales growth during COVID-19 is non-linear (Central Bank of Chile, 2020), we include two dummies for sales growth: a dummy equal to one for positive sales growth (and zero if no growth) and a dummy equal to one for negative sales growth (and zero if no growth). Other Program Use ${ }_{i}$ is a dummy equal to one if firm $i$ uses the other government program and is zero otherwise. The results are robust to using instead a logit model or a linear probability model. ${ }^{23}$ Because we measure risk ex-ante, this variable does not reflect the risk related to the COVID-19 pandemic. To capture how ex-post characteristics are related to program selection, we use sales growth, the other program use, and fixed effects.

Table 2 reports the selection results for banked firms, for which we have a more accurate measure of risk. ${ }^{24}$ Riskier firms are more likely to obtain a guaranteed loan (Column 1). For example, a shift from $25 \%$ to $75 \%$ in the risk distribution implies an increase of 6.5 percentage points in the likelihood of using the program $(=0.647 \times(0.13-0.03))$. This represents an increase of $16 \%$ relative to the average likelihood of using the program $(=0.065 / 0.505)$ in this regression sample. After adding industry and municipality fixed effects, the magnitude of the effect declines, indicating significant variation in the risk of firms operating in different industries and located in different municipalities (Column 2). That said, we find that even within firms operating in the same industry and located in the same municipality, riskier

\footnotetext{
${ }^{23}$ The risk regressor of Equation (2) is itself an estimated variable (estimated from Equation 1), which could bias standard errors. Given the computational difficulties in calculating bootstrapped standard errors in non-linear probit models with two sets of fixed effects (industry and municipality), we block-bootstrap the standard errors of the model's linear version. The standard errors remain essentially unchanged relative to the non-adjusted standard errors and can be found in Online Appendix Table A4. We repeat this procedure for all the other probit regressions that contain risk as an independent variable; we omit reporting those results to save space, but they remain robust.

${ }^{24}$ Because the risk regressor is estimated based on a vector of ex-ante firm characteristics (including age and size), the probit model of Equation (2) indirectly controls for all those firm characteristics.
} 
firms are significantly more likely to use the program.

What drives this program participation, supply or demand? The answer is both. The demand for credit exceeds the program allocation and $97 \%$ of the available credit is allocated by the end of 2020, with banks deciding which firms receive credit or not.

Our data allow us to decompose the probability of obtaining a guaranteed loan as the product of the probability of applying for the loan (credit demand) and the probability of the bank approving the loan conditional on receiving an application (credit supply). Riskier firms are more likely to apply for a guaranteed loan, suggesting adverse selection into the credit program (Table 2, Columns 3-4). The effect declines but remains significant after adding industry and municipality fixed effects. However, conditional on applying to the program, riskier firms are less likely to obtain the loan, indicating that banks screen loans and provide less credit to firms more likely to default (Table 2, Columns 5-6). The coefficient for approvals remains unchanged after adding industry and municipality fixed effects, suggesting that banks follow a broad approval policy, across industries and municipalities.

Our findings indicate that our results are neither driven by nor particular to the pandemic. Firms experiencing both positive and negative sales growth during the first months of the pandemic are significantly more likely to obtain a guaranteed loan relative to firms with no sales growth. Firms with either positive or negative sales growth are $19 \%$ more likely to use the credit program. That is, guaranteed credit flows equally to firms that are differently hit (within an industry and municipality) by the pandemic.

We contrast the results of the credit program with the employment program (Table 2, Columns 7-8) using an analogous probit model. Participation in the employment program is much more clearly specific to a pandemic-driven crisis. Firms that suffer negative sales growth are more likely to use the employment program (11.2\%) compared to firms with positive sales growth $(5.3 \%)$. Because firms negatively affected by the pandemic lose less by shutting down, the (opportunity) cost of participating in the employment program is lower, so they have more incentives to use it. Moreover, firms that use the employment program are $9.5 \%$ more likely to obtain a guaranteed loan, while firms that participate in the credit program are $5.6 \%$ more likely to participate in the employment program. These results suggest that the credit and employment programs are used as complementary public policies.

Unlike the credit program, firms with different risk are equally likely to use the employment program, after controlling for industry and municipality fixed effects. This indicates that the employment program leads to less adverse selection than the credit program. This result is consistent with the fact that program credit is cheap - the real 
interest rate is close to zero - and the interpretation that interest in the program is based on cheap credit. ${ }^{25}$ Instead, the employment program is more expensive as firms must shut down (or at least forego the output from the workers with frozen labor contracts) and stop receiving or reducing their income from operations.

Similar patterns arise when we look at the effect of lockdowns on program participation using a difference-in-differences analysis to test how firms subject to lockdown mandates use public programs. We combine the difference-in-differences with a spatial regression discontinuity that exploits the dynamic heterogeneity across municipalities in the timing of lockdown mandates. We find that firms under lockdown are more likely to use the employment program, but not the credit program. (Details are shown in Online Appendix A.) These results support our claim that guaranteed credit flows across the board, while participation in the employment program is much more driven by the negative effects of the pandemic.

Lastly, we note that the selection results remain unchanged when we include both banked and unbanked firms in the estimation (Online Appendix Table A6). For this regression, we use a different measure of risk. The risk of banked firms is based on real and financial data, while that of unbanked firms is calculated using only real data. To simplify, we report only results with industry and municipality fixed effects. The selection results are also robust to using the ex-ante spread as a simple and direct measure of risk instead of using the predicted default probability from our estimated default probability model. ${ }^{26}$

\section{Effects on Firm Indebtedness}

We next study the effect of using the credit program on debt at the firm level. To do so, we estimate the following cross-sectional regression:

$$
\frac{\Delta \text { Debt }_{i}}{\text { Sales }_{i}}=\beta \text { Program Use } e_{i}+\gamma \text { Risk }_{i}+\delta \text { Sales Growth }_{i}+\alpha_{s}+\alpha_{m}+u_{i} .
$$

$\Delta$ Debt $_{i}$ is the growth in (net) bank debt during the entire year of 2020, normalized by sales in 2019. This ratio focuses on the change in indebtedness, holding constant sales and thus abstracting from the sales decline in 2020. ${ }^{27}$ The dummy Program $U s e_{i}$ is defined as

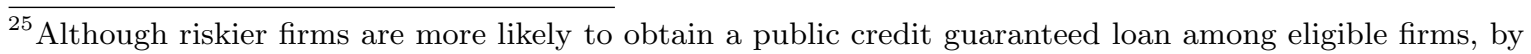
design the program excludes the riskiest firms from the economy. If we add those ineligible firms to the estimation, we still find that riskier firms are more likely to obtain the guaranteed loan. On the other hand, when we add ineligible mega firms to the estimation, the size of the effect of risk increases, which is consistent with the fact that these mega firms entail low risk. When we compare the firms that obtain the credit program to all firms in the economy, including those that are ineligible by risk and size, the effect of risk remains significant. See Online Appendix Table A5 for details and further results.

${ }^{26}$ Results can be found in Online Appendix Table A8.

${ }^{27}$ We normalize the debt change by sales instead of assets because sales are more accurately measured and audited by the tax authority than assets. However, our results are robust to normalizing the change in debt by assets and net worth in 2019 and to normalizing by 2020 sales, assets, and net worth.
} 
previously reported. Risk $k_{i}$ corresponds to the fitted default probability value derived from the firm-level default regression estimates.

Banked and unbanked firms that use the credit program increase their indebtedness by 14.5 and 13.0 percentage points, respectively, relative to non-participating firms (Table 3, Columns 1 and 2). These are sizable effects when compared to the initial leverage ratio of $29 \%$ for banked firms and $0 \%$ for unbanked firms (which by definition have no previous bank debt). Firms with both positive and negative sales growth increase their leverage during 2020, reaffirming that the credit granted is not specific to the pandemic effects on firm performance. ${ }^{28}$

Additional evidence suggests that the increase in firm indebtedness can be causally attributed to the credit program per se. We conduct a regression discontinuity analysis exploiting the size eligibility threshold of the credit program to support this claim. Results can be found in Online Appendix B. Although these regression discontinuity results are informative to attribute causality, we do not employ them systematically in our paper because they cannot be used to capture the full distribution of firms and thus the aggregate effects. They just estimate the effects for the very largest firms that lie around the discontinuity. ${ }^{29}$

Next, we decompose the change in indebtedness into the change in public guaranteed debt and non-guaranteed debt. By construction, public guaranteed debt needs to increase for firms participating in the program. We find that indebtedness coming from public guaranteed debt increases by 13.9 and 11.8 percentage points for banked and unbanked firms, respectively (Table 3, Columns 3 and 4). On the other hand, participating in the credit program could lead to higher or lower non-guaranteed debt. We find that indebtedness coming from nonguaranteed debt also increases, although the magnitude of the effect is significantly smaller (Columns 5 and 6). In other words, guaranteed and non-guaranteed debt are to some extent complementary to each other during the pandemic.

Having shown that the increase in debt occurs mostly through participating in the credit program, we next study how risk is related to the accumulation of this type of debt. We find that, within credit program users, riskier firms end up with more public guaranteed debt than safer firms, and this holds for both banked and unbanked firms (Table 4, Columns

\footnotetext{
${ }^{28}$ The relation between indebtedness and the employment program is much weaker than with the credit guarantee program. The effect is significant but an order of magnitude smaller than the effect for the credit program (Columns 1 and 2). In addition, firms that participate in both programs accumulate less debt. This result suggests that the complementarity between the credit and employment programs, also shown in the selection regressions, helps firms to contain their indebtedness during the crisis.

${ }^{29}$ Additional regression discontinuity exercises on other variables (such as real outcomes) do not show an effect of the program, as we do observe for leverage. This type of analysis could be useful for further work that does not focus on the aggregate effects but is interested in variations around different discontinuities.
} 
1 and 2). The selection results from the previous section show that riskier firms are more likely to participate in the credit program (an expansion of the extensive margin). The results in this section show that, conditional on participating in the credit program, riskier firms end up with more guaranteed debt (an expansion of the intensive margin). In contrast, the relation between risk and non-guaranteed debt is negative, significant for banked firms and not significant for unbanked firms (Columns 3 and 4). That is, in the absence of a public guarantee, banks lend to safer firms. The results indicate that the existence of a public credit guarantee program changes the way banks allocate credit across the risk distribution of firms.

\section{$7 \quad$ Aggregate Implications}

In this section, we analyze the aggregate implications of the credit guarantee program. We first study how indebtedness increases for different types of firms and how those firms, in turn, contribute to the rise in aggregate corporate debt during 2020. We then study how the risk that the credit program expansion entails is handled and shared between the banking system that grants the loans and the government that guarantees those loans. While Section 4 uses official aggregate data to display the patterns, here we compute the aggregate statistics from the micro data, allowing us to connect the micro and macro estimates. ${ }^{30}$

\subsection{From Firm Indebtedness to Aggregate Indebtedness}

To determine how micro-level indebtedness reflects on the overall economy, we partition firms into four groups according to their predicted default risk, from high risk to low risk. The change in indebtedness in each risk group is obtained by multiplying the within-group change in the indebtedness of firms in each risk group by the weight of that group of firms in aggregate economic activity (measured by sales):

$$
\underbrace{\frac{D_{g t}-D_{g t-1}}{Y_{g t-1}}}_{\text {Within Change }} \underbrace{\omega_{g t-1}}_{\text {Weights }}=\underbrace{\frac{D_{g t}-D_{g t-1}}{Y_{g t-1}} \omega_{g t-1}}_{\text {Group Change }} .
$$

We then obtain the aggregate change in indebtedness, relative to aggregate sales, by adding the contribution of leverage of the different risk groups:

$$
\sum_{g \in G} \underbrace{\left(\frac{D_{g t}-D_{g t-1}}{Y_{g t-1}} \omega_{g t-1}\right)}_{\text {Group Change }}=\underbrace{\frac{\Delta D_{t}}{Y_{t-1}}}_{\text {Aggregate Change }} .
$$

$G$ is a partition of firms according to risk, and $g$ indexes a group of firms. $Y_{g t-1}=\sum_{i \in g} y_{i t-1}$

\footnotetext{
${ }^{30}$ The size of the aggregate indebtedness from the micro data are a bit smaller than that obtained from the aggregate data because we do not use information on indebtedness for firms that have missing information on sales or have not submitted their data to the tax authority.
} 
is the sales of group $g$ of firms, where $y_{i t-1}$ denotes firm-level sales. $D_{g t}=\sum_{i \in g} d_{i t}$ is the stock of debt of group $g$ of firms, where $d_{i t}$ denotes firm-level credit stock. $\omega_{g t-1}=Y_{g t-1} / Y_{t-1}$ is the weight of group $g$ in aggregate sales in year $t-1 . \Delta D_{t}$ is the aggregate yearly change in debt between $t$ and $t-1$ (between 2020 and 2019). $Y_{t-1}$ is aggregate sales in 2019. ${ }^{31}$

Table 5 presents the results of this aggregation. We first consider the set of credit program users (Panel A). The change in indebtedness for these firms takes into account both program and non-program debt. Consistent with the previous section, riskier firms experience larger within-group changes in indebtedness: the leverage of high-risk firms increases by 10.7 percentage points, while the leverage of low-risk firms increases by 9.18 percentage points (Column 1). Nevertheless, riskier firms represent a smaller share of aggregate activity: high-risk firms represent only $7.1 \%$ of countrywide sales compared to the low-risk firms that represent $41.2 \%$ of aggregate sales (Column 2). As a result, the contribution of high-risk firms as a group to overall indebtedness is smaller, 0.11 percentage points, than the contribution of low-risk firms, 0.53 percentage points (Column 3). The small weight of riskier firms in the aggregate therefore mitigates the micro adverse selection documented in the previous sections. Summing across all risk groups shows that the indebtedness of firms that use the credit program increases by 1.35 percentage points. This change in debt corresponds to $2.9 \%$ of the GDP reported by macro statistics. Those firms experience an increase of $3.6 \%$ of GDP in guaranteed credit (Table 6) and a decline in non-guaranteed credit.

Next, we extend the analysis to include the non-program users. ${ }^{32}$ The leverage of program users increases by 9.71 percentage points during 2020, while the leverage of nonusers actually falls by 1.06 percentage points (Panel B). However, given that program users have a low weight in the aggregate economy ( $13.9 \%$ compared to $86.1 \%$ of non-users), total indebtedness across all firms increases by only 0.44 percentage points. Last, partitioning all active firms (users and non-users) by risk confirms that the higher the risk, the larger the within-change in debt (Panel C). But the higher the risk, the smaller their weight in the economy, attenuating the increase in aggregate risk. ${ }^{33}$ This analysis shows why the micro results presented in previous sections can have a relatively small impact at the macro level.

\footnotetext{
${ }^{31}$ In alternative estimations, we use value added instead of sales, obtaining similar results. But the magnitude of change in debt relative to value added are larger than those relative to sales (as sales is a measure of gross output). We report the estimates relative to sales to link it better to the micro part and because, unlike value added, most firms in the economy report sales.

${ }^{32}$ We use Equations (4) and (5) to partition firms into credit program users and non-users and measure the contribution of these groups to overall indebtedness.

${ }^{33}$ In unreported results, we decompose indebtedness into two additional margins: banking status and size. Across the different partitions of firms, large increases in firm leverage within groups happen for firms with a relatively small weight at the aggregate level.
} 


\subsection{Risk Sharing between Banks and the Government}

Banks and the government share, absorb, and mitigate the risks that the credit program entails by dealing with the expected default risk from the loans granted, unexpected credit risk, and funding needs for the banks. To understand the risks involved, it helps to measure the magnitude of the program allocation across groups of firms. We focus here on firms by risk category. ${ }^{34}$

Micro data indicate that by the end of 2020, banks provide guaranteed loans worth US $\$ 11,467$ million, or $4.6 \%$ of 2019 GDP, including loans to firms and natural persons who borrow as firms under the program (Table 6, Panel B, Columns 1 and 2). These loans are distributed across firms of different risk categories. High-risk firms receive $7 \%$ of the guaranteed loans to firms, whereas low- and medium-low-risk firms receive 65\% (Panel A, Column 3). That is, most of the loans go to safer firms. In fact, the actual distribution of credit under the program roughly matches the weights that firms have in the economy according to sales (compare with Panel A, Column 2 of Table 5 or see Online Appendix Figure A4). Therefore, the aggregate debt allocation across risk groups (including guaranteed and non-guaranteed debt) mentioned in the previous section is basically the same as the share that each risk group receives of the guaranteed credit. For both total and guaranteed debt, larger, safer firms are the ones that receive the bulk of the credit, with their larger allocation given by their ex-ante weight in the economy according to sales.

The main risk that pervades the program's loan allocation is the loss from default of different tranches of the loan portfolio. This risk could be significant because the program targets firms smaller than the typically safe mega firms (even when some precautions are taken to exclude the riskiest firms in the country). To gauge the magnitude of this default risk and how it is distributed, we first estimate the default probability for 2020 for firms in each risk bin, defined by the different levels of coverage of the credit guarantee. To do so, we use the coefficients of the default risk model in Section 5 and plug in the 2019 information for the different regressors. This yields predicted default values for 2020 for firms that use the credit program across different categories. As expected, the predicted default probability declines monotonically with risk, going from $18.17 \%$ for high-risk firms to $2.05 \%$ for low-risk

\footnotetext{
${ }^{34}$ As an alternative, Online Appendix Table A9 reports the results of partitioning firms by size. This is useful because the public guarantee varies by size (from $85 \%$ for small firms to $60 \%$ for large firms, as explained in Section 4), effectively determining how firms and the government share risk. Furthermore, the size categorization allows us to cover all firms in our sample, permitting a better mapping between the debt levels computed from micro and macro data.
} 
firms (Panel A, Column 4). ${ }^{35}$

We then calculate a measure of total credit risk (i.e., expected loss) for each bin size by multiplying the dollar value of program loans by the predicted default probability. Expected loss technically ought to be equal to the probability of default times the loss given default. Given data restrictions on loan recovery rates, in the analysis we assume that the loss given default equals one, i.e., we assume that banks do not recover anything after a borrower defaults (no partial repayment). Our calculations therefore imply an upper bound of the true total credit risk. We return to this distinction in our structural model in Section 8.

As a proportion of GDP, the total credit risk corresponds to an expected credit loss of $0.27 \%$ (Panel A, Column 8). The contribution to expected loss is similar across risk categories because the larger amounts granted to low-risk firms and their smaller default probability compensate across buckets. When considering all guaranteed loans to firms and natural persons, the expected credit loss is $0.44 \%$ of GDP (Panel B, Column 8), which corresponds to a $9.56 \%$ default probability of the guaranteed credit $(0.44 \% / 4.6 \%=9.56 \%)$ (Panel B, Column 4). This estimate of expected loss seems large relative to the credit granted because it is conservative. It not only imputes the highest default probability to firms with no risk data and to natural persons but also ignores any partial repayment or recovery from firms that eventually default. Still, for a program that channels significant credit to SMEs, it is a useful benchmark to assess the expected loss based on historical default estimates.

In terms of risk sharing between the government and banks, the fraction of credit risk effectively guaranteed by the government in case of default depends on the guarantees, which vary by firm size, after the corresponding deductible is applied. ${ }^{36}$ Because of the significantly large first-loss deductible relative to the default probability, banks absorb the vast majority of the expected loss. The total credit risk estimated to be borne by the government is $0.15 \%$ of GDP (Panel B, Column 9), while that borne by banks is $0.29 \%$ of GDP (Panel B, Column 10). Thus, two-thirds of the total credit risk derived from the expected loss from default $(0.29 \% / 0.44 \%=66 \%)$ is absorbed by the banks and one-third by the government.

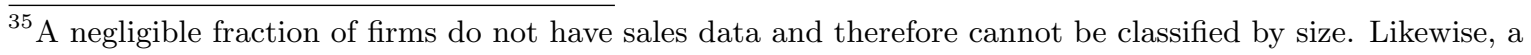
small fraction of firms do not have data to be classified in a risk category. To be conservative, we assume that firms with no sales or risk data (including natural persons) have the default probability of the riskiest group of firms.

${ }^{36}$ To calculate the effective guarantee, we consider the deductible and the guaranteed amount after applying the deductible, both of which depend on firm size. The effective guarantee is calculated as follows:

Effective Guarantee $=(($ Default Probability - Deductible $) \times$ Nominal Guarantee $) /$ Default Probability.

The deductible is reduced to zero for SMEs starting in July. Given that most of the guaranteed credit is granted in the program's first months (May and June), for the analysis, we use the values of the deductible established at the beginning of the program.
} 
Banks cover for this credit risk by increasing their loan-loss provisions (by roughly US $\$ 1$ billion). They also contain credit risk by more strongly rejecting applications from larger risky firms, which would be more costly for banks to absorb in case of default because of their size and the lower effective guarantee (Table 7). In fact, the absolute value of the coefficient on risk of bank approvals (in response to loan applications) triples when moving from the small firms to the large ones. That is, banks are more sensitive in their responses to loan applications from large risky firms than to those of small risky firms.

Credit risk has an expected and unexpected component. The expected component is the expected loss from a loan exposure, while the unexpected component is the loss that exceeds the expectation (i.e., tail risk). As explained above, the program's first-loss deductible is large relative to the expected default probability, so banks absorb the vast majority of the expected credit risk. On the other hand, the deductible is small relative to the default probability in a tail event, meaning that the government absorbs most of the unexpected credit risk. In Appendix A, we show that the transfer of unexpected credit risk from banks to the government effectively reduces banks' risk-weighted assets, increasing the capital adequacy ratio of the banking industry in Chile.

\subsection{How the Environment and Policy Affect Aggregate Risk}

To understand how the environment and features of the policy influence the low aggregate risk outcome, we perform a series of sensitivity analyses that yield five different empirical counterfactual scenarios. In each, we modify different dimensions of the environment and policy and recalculate the expected loss over GDP derived from credit to firms (excluding natural persons). The scenarios are computed sequentially, but the different dimensions could interact with each other in practice. Whereas these calculations shed light on how the different mitigating factors might affect aggregate risk, they take the demand for credit and default rates as exogenous. We later perform more formal, quantitative counterfactuals in a model of endogenous credit and default presented in Section 8.

Table 8 presents the results of this measure of aggregate risk, including the baseline scenario originally reported in Column 8 , Table 6 (repeated here in line 1 ). We begin with two mitigating factors that are an equilibrium outcome and are related to the environment. In the first alternative scenario (line 2), we compute aggregate risk with a higher average default rate. We increase default rates for all groups of risk by 5 percentage points, which is equivalent to the increase in the average default rate experienced in Chile during the 2008 global financial crisis. Under this alternative scenario, aggregate risk is $0.44 \%$, compared to a baseline for firm loans of $0.27 \%$. As a second scenario (line 3), we compute aggregate risk 
such that all the credit of the program that goes to firms (3.6\% of GDP) is allocated to the riskiest group of firms. Under this alternative scenario, aggregate risk jumps to $0.65 \%$.

We then explore the role of three mitigating factors driven by the policy design. As a third alternative scenario (line 4), we explore the case in which there is complete guarantee of the loans and no deductible for banks. To generate this scenario, we assume that the funds are allocated based on demand and that banks play no screening role. That is, supply would be fully passive as banks would not absorb any risk in the allocation of credit. We use the observed demand as a measure of what firms would demand in this scenario, keeping the cap of the program at three months of sales as the maximum amount of credit that could be granted. Under this alternative scenario, we find that aggregate risk increases to $0.77 \%$. As the fourth alternative scenario (line 5), we explore a similar case as in the previous one but instead increase the loan cap from three to 12 months of sales. In this case, aggregate risk increases the most, to $1.95 \%$ of GDP, more than half of the total credit granted to firms. As a fifth scenario (line 6), we implement a case in which there is no eligibility constraint for firms with high default (i.e., firms with past due payments exceeding 30 days). These firms have an ex-ante expected default rate of $12.6 \%$. We approximate their potential demand as three months of sales, that is, we assume that these firms would demand the maximum possible credit they could obtain. Under this scenario, we find an aggregate risk of $0.69 \%$.

From these alternative scenarios, we conclude that the factors related to the existing environment seem to be less important for aggregate risk than mitigating factors driven by the policy design. First, unless one were to relax the cap on the loan amount and transfer the full risk to the government, these comparative statics cannot deliver an aggregate risk higher than $1 \%$ of GDP or $20 \%$ of the total amount of credit allocated by the program. Second, relaxing the level of the guarantee by itself by letting banks lend freely seems to be the most important parameter that can affect aggregate risk after relaxing the amount cap. This likely underestimates the true additional risk, since risks would be presumably greater if one were to allow requested loans to endogenously respond to this increased cap. Third, although the aggregate risk of the program is large relative to its size, the aggregate risk measured by the expected loss to GDP is small. Just redistributing the allocated credit toward the existing risky firms or even increasing the default rate does not substantially raise the expected loss to GDP. To increase aggregate risk, the available supply of credit would need to rise and the demand would need to exhaust it. Having a larger mass of risky firms could also increase aggregate risk.

These counterfactual calculations are very informative, but they account for neither 
the complete potential endogenous response of firms to these parameters nor the partial repayment of at-risk credit in any scenario. To do so, we turn to the model to perform structural counterfactuals. This complements our understanding of how ingredients of our results respond to the environment and policy.

\section{Model}

In this section, we use a simple model of heterogeneous firms' credit and default decisions to help (i) motivate the empirical predictors of risk in our default probability model, (ii) quantify and understand the relation between elements of the credit policy and aggregate outcomes in the context of standard theory where credit and default respond endogenously, (iii) simulate potential outcomes under a systemic shock, and (iv) more closely quantify the government's burden in a world in which default generally involves partial repayment.

Although we have micro evidence of potential adverse selection (at least based on observables), the key message of our aggregate empirical analysis is that this appears relatively unimportant in the aggregate because most credit goes to relatively safe firms. Hence, we abstract from informational frictions, instead following the existing literature of firm finance with endogenous default (e.g., Bernanke et al., 1999; Cooley and Quadrini, 2001; Gilchrist et al., 2014) and especially Covas and Den Haan (2012). Moreover, given the suddenness of the pandemic crisis and credit guarantee, we model a simple static problem taking firm equity as given. We calibrate the model to our data on eligible firms, illustrate the expansion and distribution of credit from the program, and quantify the program's impact on aggregate credit and default under various policies and shocks. The latter is helpful because it relaxes a key assumption in our above empirical analysis that default rates follow historical values.

\subsection{Firm's Problem}

Consider a firm with equity, $e$, and expected productivity, $z$, that decides how much to borrow, $b$, given an interest rate schedule for borrowing, $r_{b}(b ; e, z) .{ }^{37}$ Its profits (i.e., revenues minus expenses before debt servicing), $\pi$, depend on its expected productivity, $z$, capital (i.e., total assets), $e+b$, and a stochastic revenue shock, $\varepsilon$ :

$$
\pi=\varepsilon z(e+b)^{\alpha},
$$

\footnotetext{
${ }^{37}$ We use the term equity in the model to be consistent with the existing literature of firm finance with endogenous default. But equity is equivalent to net worth (i.e., assets minus debt), as used in the empirical part of the paper.
} 
where $\varepsilon$ is a random variable with $E(\varepsilon)=1$, continuously distributed over $\mathbb{R}^{+}$according to a cumulative distribution function, $\Phi(\cdot)$. Capital depreciates at rate $\delta .^{38}$ Given its debt and equity, the firm defaults when its value turns negative:

$$
\varepsilon z(e+b)^{\alpha}+(1-\delta)(e+b)-\left(1+r_{b}(b ; e, z)\right) b<0 .
$$

When this holds with equality, it defines a threshold lower bound shock level $\underline{\varepsilon}$ below which the firm defaults:

$$
\underline{\varepsilon}(b ; e, z)=\frac{\left(\delta+r_{b}(b ; e, z)\right) b-(1-\delta) e}{z(e+b)^{\alpha}} .
$$

Because the user cost of capital, $\delta+r_{b}(b ; e, z)$, is positive, the default threshold is increasing in debt to (expected) revenues, one of our empirical proxies for risk. ${ }^{39}$ An immediate corollary is that the probability of default is increasing in this measure of leverage, justifying the use of leverage as an empirical predictor of risk in our default probability model. This is only a partial measure, however, because the pattern is true for a given distribution of $\varepsilon$, $\Phi(\cdot)$.

Given this optimal default behavior, the firm chooses its debt to maximize its expected value:

$$
\max _{b} \int_{\underline{\varepsilon}(b ; e, z)}^{\infty}\left[\varepsilon z(e+b)^{\alpha}+(1-\delta)(e+b)-\left(1+r_{b}(b ; e, z)\right) b\right] \Phi(d \varepsilon) .
$$

After integrating and substituting in the threshold condition, this simplifies to

$$
\max _{b} z(e+b)^{\alpha} G(\underline{\varepsilon}(b ; e, z)),
$$

with

$$
G(\underline{\varepsilon}(b ; e, z)) \equiv \int_{\underline{\varepsilon}(b ; e, z)}^{\infty} \varepsilon \Phi(d \varepsilon)-(1-\Phi(\underline{\varepsilon}(b ; e, z))) \underline{\varepsilon}(b ; e, z) .
$$

The first term captures the expected profits, while the second captures the value of undepreciated capital net of expected repayment.

\subsection{Banks}

Competitive banks lend to firms and face a constant cost of capital, $(1+r)$. In the event of default, the lender earns

$$
\varepsilon z(e+b)^{\alpha}+(1-\delta)(e+b)-\mu z(e+b)^{\alpha},
$$

where $\mu z(e+b)^{\alpha}$ captures the cost of verifying the state, which is proportional to the typical firm profits.

Given perfect competition, loan pricing ensures zero profits:

\footnotetext{
${ }^{38}$ We abstract from explicit labor and material costs. If these costs are a fixed proportion of capital, however, they are easily incorporated into the depreciation term as in our calibration below.

${ }^{39}$ In the special case of $\alpha=1$, one can also see that the default threshold is increasing in debt to total assets, $b /(e+b)$.
} 


$$
\begin{gathered}
(1-\Phi(\underline{\varepsilon}))\left(1+r_{b}\right) b+\left(\int_{0}^{\underline{\varepsilon}} \varepsilon z(e+b)^{\alpha} \Phi(d \varepsilon)+\Phi(\underline{\varepsilon})\left((1-\delta)(e+b)-\mu z(e+b)^{\alpha}\right)\right) \\
-(1+r) b=0,
\end{gathered}
$$

where the first term is income in the event of full repayment, the second term is income under default net of state verification costs, and the third term is the cost of capital. After some simplifying algebra, the equilibrium interest rate is therefore

$$
r_{b}(b ; e, z)=r+\frac{z(e+b)^{\alpha}}{b}\left(\Phi(\underline{\varepsilon}(b ; e, z)) \mu+\int_{0}^{\underline{\varepsilon}(b ; e, z)}(\underline{\varepsilon}(b ; e, z)-\varepsilon) \Phi(d \varepsilon)\right) .
$$

Here the borrowing rate exceeds the cost of capital by a default risk premium. ${ }^{40}$ This justifies our use of the borrowing rate as an additional empirical predictor for risk.

Is $r_{b}(b ; e, z)$ increasing in $b$ ? The default premium on the right varies inversely with the leverage ratio of debt to expected revenues, $b /\left(z(e+b)^{\alpha}\right)$, and directly with the sum of a term combining the default probability and the state verification cost parameter, $\Phi(\underline{\varepsilon}(b ; e, z)) \mu$, and another term capturing the total productivity lost below the break even. The last two terms are increasing in $b$ since $\partial \underline{\varepsilon} / \partial b>0$. Whether the first term is decreasing in $b$ depends on whether the marginal product of capital exceeds one.

\subsection{Credit Program}

From the firm's perspective, the competitive banking system and supply of credit is captured by Equation (12), which is a constraint in the firm's problem. We model the introduction of the credit program as a comparative static exercise. We introduce key features of the Chilean banking framework and credit program into the model in three fashions.

First, we establish an initial statutory interest rate cap on credit, $\bar{r}_{b, 0}$. This leads to an additional constraint:

$$
r_{b}(b ; e, z)=r+\frac{z(e+b)^{\alpha}}{b}\left(\Phi(\underline{\varepsilon}(b ; e, z)) \mu+\int_{0}^{\underline{\varepsilon}(b ; e, z)}(\underline{\varepsilon}(b ; e, z)-\varepsilon) \Phi(d \varepsilon)\right) \leq \bar{r}_{b, 0},
$$

which effectively defines a limit of available credit $b$ as a function of equity and productivity. Indeed, for low productivity firms, available credit may be zero. A first element of the credit program is a substantially lower interest rate cap on public guaranteed credit, which we model as $\bar{r}_{b, 1}<\bar{r}_{b, 0}$.

Second, we introduce the partial guarantee against default, the part of the program in which the government agrees to reimburse a fraction $\chi$ of defaulted credit. We model this as banks bearing only a fraction $(1-\chi)$ of defaulted credit payments. Hence, combining these

\footnotetext{
${ }^{40}$ Substituting in for $r_{b}(b ; e, z)$ and further simplifying yields a useful and insightful equivalent expression for the lender's zero profit condition:

$$
z(e+b)^{\alpha}(1-G(\underline{\varepsilon}(b ; e, z))+(1-\delta)(e+b)-\mu \Phi(\underline{\varepsilon}(b ; e, z)))-(1+r) b=0,
$$

where the bank's expected revenues include the share, $1-G(\underline{\varepsilon}(b ; e, z))$, that does not go the firm and the undepreciated capital, while its costs include expected default costs and the loan's direct cost.
} 
first two elements, the interest rate constraint under the program becomes

$$
\begin{gathered}
r_{b}(b ; e, z)=r+\frac{z(e+b)^{\alpha}}{b}(\Phi(\underline{\varepsilon}(b ; e, z)) \mu \\
\left.+(1-\chi) \int_{0}^{\underline{\varepsilon}(b ; e, z)}(\underline{\varepsilon}(b ; e, z)-\varepsilon) \Phi(d \varepsilon)\right) \\
\leq \bar{r}_{b, 1 .}
\end{gathered}
$$

It is straightforward to derive the expected defaulted payment on an equilibrium loan:

$$
z(e+b)^{\alpha}\left(\Phi(\underline{\varepsilon}(b ; e, z)) \underline{\varepsilon}(b ; e, z)-\int_{\infty}^{\underline{\varepsilon}(b ; e, z)} \varepsilon \Phi(d \varepsilon)\right) .
$$

The expected government subsidy is then $\chi$ times this expression. For simplicity, we abstract from two features of the guarantee: (i) the dependence of the level of partial guarantee, $\chi$, on firm size and (ii) the deductible. We calibrate $\chi$ conservatively by choosing the largest value. Both assumptions are conservative in assessing potential risks and the government burden.

Third, we introduce an exogenous increased willingness to lend that accompanies the program, which might indirectly capture the government's decision to more decisively support firms through the banking sector during the pandemic. To formally introduce this factor, we consider $r$ as a sum of the cost of capital to banks, $\tilde{r}$, and a perceived proportional intermediation cost, $c$, which includes a return to equity. Clearly, it is the sum of the two that matters for the lending rate that banks are willing to lend to safe borrowers, but we distinguish between the two to emphasize that willingness to lend can come from different forces. A drop in the cost of capital $\tilde{r}$ can capture the liquidity facilities offered by the Central Bank of Chile discussed in Online Appendix A. A decline in $c$ under the policy could capture the fact that banks use fewer resources to screen and process loans. To simplify and to stick to a more standard model in the literature, we abstract from other aspects of the program touched upon in the empirics (such as eligibility requirements and the choice between program and non-program credit). All of this makes our model best viewed as a model of eligible firms that, while appropriate for thinking about the program's impact on firm indebtedness, is less appropriate for thinking about the extensive margin choices of borrowing or program participation.

Before turning to the quantitative exercise, we calibrate the model to key aggregates, including default rates, interest rates, and moments capturing the distributions of debt ratios, equity, and sales across the economy. Importantly, the fact that average (credit-weighted) default rates and interest rates are both roughly $4 \%$ implies substantial repayment is necessary even during default in order for lending to cover costs. We present here the parameter values related to the credit program, while the calibration details are explained in Online Appendix C. We start with pre-guarantee parameters of $\chi=0$ (absence of a government guarantee scheme) and $\bar{r}_{b, 0}=0.2$, equal to the regulated maximum interest rate. The multi-tiered partial 
guarantee scheme in which guarantees vary by firm size is then collapsed to a single guarantee of $\chi=0.8$. We set $\bar{r}_{b, 1}=0.035$, the statutory maximum interest rate under the program. To capture the overall increased willingness to lend, we lower the cost of intermediated capital by 1.9 percentage points. ${ }^{41}$ One key parameter of interest that we calibrate is underlying revenue risk, $\sigma_{\varepsilon}^{2}$, the variance parameter of $\Phi(\cdot)$, the lognormally distributed realizations of revenue. Heterogeneity in revenue risk across firms is captured by the fact that $\sigma_{\varepsilon}^{2}$ is itself lognormally distributed across firms. Other key parameters capturing the distribution of firms include the variance of $\log$ productivity, $\sigma_{z}^{2}$, the variance of $\log$ equity, $\sigma_{e}^{2}$, the mean level of $\log$ equity, $\bar{e}$, and the correlation between $\log$ productivity and log equity, $\rho$.

\subsection{Credit Program Implications}

Moving to the results, Figure 2 illustrates the credit variables for a moderate value of productivity, $z=1.8$. We plot equity on a $\log$ basis to show details for low levels of equity. ${ }^{42}$ The left panels illustrate these functions for firms with $\sigma_{\varepsilon}=0.22$, essentially the middle of the distribution. The solid dark line illustrates the results for a firm in the benchmark banking system. These firms are overwhelmingly low risk. Default becomes non-negligible only at equity levels below one (top-left panel) because equity acts as both collateral and firm value, deterring default. Nonetheless, risks remain relatively low since the default rates remain below 0.08 (i.e., $8 \%$ ) even with zero equity for firms with average productivity and risk. The borrowing rates (second-left panel) reflect risk premia, which also remain low. At moderate levels of equity, premia are zero and borrowing rates equal the cost of capital, $r$, but interest rates do not exceed $6 \%$ for these firms.

The figure also shows that the debt levels exhibit a hump shape (third-left panel). At low levels of equity, additional equity leads to more borrowing since it lowers risk and borrowing rates. However, once borrowing rates converge to the cost of capital, debt declines with equity because firms are at their optimal risk-free level of capital. The firms simply substitute internal capital for external capital one for one, and consequently, firms with high equity (relative to productivity) do not borrow at all. In addition, leverage (debt to revenue) correspondingly declines with equity (fourth-left panel).

Last, the distribution of credit by equity level (bottom-left panel), constructed by multiplying the debt levels by the density of firms, $H\left(z, e, \sigma_{\varepsilon} ; \sigma_{z}^{2}, \sigma_{e}^{2}, \bar{e}, \rho\right)$, is disproportionately tilted toward safe firms. The equity distribution for this productivity is tightly distributed between 2 and 4, where default rates are low. While low-equity, higher-default risk firms have

\footnotetext{
${ }^{41}$ This value leads to an increase in lending of about $9.9 \%$ under the policy. Though not a perfect comparison, the total lending in the program equals $9.5 \%$ of the stock of firm credit in 2019 .

${ }^{42}$ We show results relative to equity to highlight the financial aspects of the model.
} 
high leverage, they constitute a negligible share of the total borrowing with substantially more credit going toward safe firms, consistent with the low overall levels of predicted credit-weighted default among eligible firms.

For comparison, Figure 2 also shows the same outcomes for firms with a higher $\sigma_{\varepsilon}$ of 0.50 , about one standard deviation out into the right tail of the revenue uncertainty distribution (right-hand side panels). We choose this far tail for clear illustrative purposes and focus first on the black lines. Default rates are much higher (top-right panel). The borrowing rate now reflects a substantial default risk premium (second-right panel), which declines with equity to the cost of intermediate capital as the default rate goes to zero. Interest rates reflect risk premia and are therefore a good measure of equilibrium risk. Indeed, the flat segment at very low levels of equity in the second-right panel, which is the result of the interest rate cap, is reflected in the default rates of the top-right panel. The default risk and substantial risk premia are higher despite lower levels of debt (third-right panel) and comparable levels of leverage (fourth-right panel). Together, the top and fourth panels display that both risk and leverage decline with equity, showing that leverage is a proxy for default risk. This is consistent with our empirical interest in leverage. Moreover, it is consistent with our empirical results that default is increasing in debt but decreasing in firm value (Table 1, Column 5). Importantly, overall credit going to these high-risk firms is quite low (bottom-right panel) since their higher risk level $\sigma_{\varepsilon}$ is less common.

The dashed lines in Figure 2 show the corresponding patterns under the credit program. The program has very little impact on the default rates of firms with the typical risk profile (top-left panel). The drop in interest rates occurs across the board (second-left panel). Despite no large drop in default risk, this happens to the typical firm because the fall in intermediation costs leads to lending at lower interest rates. The third panel shows that debt expands in response to lower interest rates (third-left panel). The expansion is across a wide range of equity, including previous non-borrowers, and thus the increase in debt includes both an intensive and extensive margin. The fourth panel down shows that leverage correspondingly increases (fourth-left panel). Most of the expanded credit is for safe firms (bottom-left panel).

The program has somewhat different impacts on high-risk firms (right panels). Among other things, it affects firms with substantial default risk (second-right panel). The drop in interest rates from the policy is stronger for riskier firms (second-right panel). This is the result of intermediation costs dropping, the guarantee lowering the needed risk premia, and the statutory cap declining (which is binding for many more low-equity firms). The cap induces banks to grant credit to firms with lower default rates than in the benchmark 
(top-right panel) despite the partial credit guarantee. The statutory rates are simply much lower than they would lend at under the benchmark in order to compensate for high default rates (a concern since the guarantee is only partial). To lower default rates, banks lend substantially less to these high-risk firms. At moderate risk levels (equity levels over 2), however, the default guarantee allows banks to take on more risk among moderate-risk firms.

Thus, given the reduced interest rate cap, debt to the riskiest firms (those with low equity and higher revenue risk) actually declines slightly under the program, though it expands somewhat for those with greater equity (third-right and fourth-right panels). Again, the riskiest firms receive a negligible share of credit under the program (bottom-right panel). The key point is that the program expands credit through lower interest rates stemming from the lower intermediation costs and partial credit guarantee. However, under both the benchmark and program, very little credit goes to firms with high default probability because they are a small share of those borrowing and the interest cap further constrains the riskiest borrowers. This result from quantitative theory is consistent with the empirical results (Tables 5 and 6).

\subsection{Counterfactual Exercises}

We then study the model's implications for aggregate credit, average borrowing rates, and ex-post delinquency measures, using the calibrated distribution of firms. For delinquency, we distinguish between (i) expected credit loss as a fraction of total credit (i.e., the expected credit-weighted default rate), (ii) the government's share of expected loss, and (iii) the expected burden on the government from the partial guarantee. The second measure is most comparable to those in Column 9 in Table 6 (but with total credit as the denominator rather than GDP), and given our simplified guarantee, it is calculated as simply $80 \%$ of expected credit loss. The final measure is the true burden of the government that accounts for the fact that even defaulted credit has partial repayment, and the guarantee is only for the unpaid portion.

We assess these ex-post measures under two scenarios: (i) the typical year's repayment used for the model calibration (and therefore lending decisions) and (ii) an unanticipated systemic shock to the distribution of productivity after credit is already granted. ${ }^{43}$ That is, we consider a combination of first and second moment shocks by lowering the productivity distribution's log mean by 4.2 log points and increasing the log standard deviation by $40 \% .{ }^{44}$

\footnotetext{
${ }^{43}$ In an alternative simulation where a systemic shock at repayment is anticipated at the time of lending, credit is dramatically reduced, interest rates are higher, and default is intermediate between the two scenarios on which we focus. However, the impacts of the policy relative to the status quo are similar to those we present for a typical year's repayment.

${ }^{44}$ Xiao (2020) estimates that the second moment of the productivity distribution increases by $40 \%$ during the Great Recession for the United States in a model similar to ours.
} 
These values capture a large but reasonable shock to the economy. Moreover, our combined shock lowers the value added of eligible firms by $4.9 \%$. Such a drop in annual output is not outside of the Chilean experience. ${ }^{45}$

We then present the quantitative predictions under the combined government policy and assess the contributions of the willingness to lend, the interest rate cap, and the credit guarantee by eliminating them one at a time (Table 9 ). The combined policy leads to a $9.8 \%$ increase in overall credit. Comparing across columns shows that "no increased willingness to lend" and the credit guarantee both contribute to this increase as eliminating them lowers credit. On the contrary, the reduction in the interest rate cap acts to limit the increase in credit. The increase in credit is accompanied by a 2.5 percentage point lower average interest rate, with all three components of the policy driving it.

The key message of the model is that despite the increased credit, the policy does not increase risk substantially in a typical year (Table 9, middle rows). Indeed, expected credit loss actually falls 0.3 percentage points under the policy. The government's share of total expected credit loss is $2.9 \%$ of total credit. Since program credit amounts to roughly $5 \%$ of GDP, this is of comparable magnitude to the expected government loss of $0.09 \%$ relative to GDP for firms in the purely empirical calculations (Table 6, Column 8). Nevertheless, the model predicts that the true burden on the government is an order of magnitude smaller because much of the debt in default is still repaid (an implication of contrasting interest rates with credit-weighted default rates). Comparing across the components shows that the lower interest rate cap on program loans plays an important role in mitigating risks: it prevents high interest rate loans that would expand credit to the riskiest firms. Without the reduction in the cap, the expected credit loss would be about $50 \%$ higher $(4.5 \%$ versus $2.9 \%)$.

Last, we come to our experiments with a systemic shock. Delinquency with the policy can be considerably higher if a large systemic shock is experienced ex-post (Table 9, bottom rows). The systemic shock itself is quite important, increasing expected credit loss to $12.7 \%$ in the benchmark. Still, we see that the policy itself does not increase the share of expected credit loss since credit flows disproportionately to safe firms. However, given the higher expected loss share, the government burden under the guarantee program is substantial. The $10 \%$ value implies a threefold increase over those in a typical year. Nevertheless, the actual burden of $1.2 \%$ remains an order of magnitude smaller. These burdens are all a result of the credit guarantee, which only has mild impacts in the model simulations. The key point here is that the model implies that a large systemic shock is necessary for the program to become

\footnotetext{
${ }^{45}$ In $1954,1973,1975$, and 1982, the drop in real GDP exceeds 5\%. In 2020, it declines by $5.8 \%$.
} 
substantially more costly because of low repayment.

\section{Conclusions}

This paper uses a large-scale episode of crisis credit together with unique financial and real data for the universe of firms and banks in Chile to shed light on the distribution of credit and the implied potential financial risks. The program implemented increases credit rapidly, substantially, and broadly to a wide class of firms. Even though the program suffers from adverse selection, in which higher risk firms disproportionately borrow, in aggregate, we find that most credit is given to relatively safe firms and macroeconomic risk stays small.

Whereas our findings are based on the COVID-19 pandemic, we can draw more general lessons about circumstances and policy actions that can limit risk while still rapidly and broadly expand credit. The loose credit conditions inevitably generate incentives for risky firms to obtain credit at low cost (the adverse selection is absent in the more costly employment program). However, adverse selection can also be mitigated by design or in practice. Firms with the highest risk can be effectively excluded through simple eligibility rules and low interest rate caps. When overall default rates are low, especially among the largest borrowers, most credit granted under easy lending policies is naturally distributed to larger and safer firms, even if riskier firms lever up the most. Government guarantees of tail credit risk can motivate banks to quickly dispense credit and engage with risky clients. Yet, when such guarantees are partial, banks have incentives to still provide effective screening. To have a sizable effect on overall risk, these programs would need to be even more generous, firms (especially risky ones) would need to borrow more, and/or the negative aggregate shock would need to be larger than those seen in recent history. These lessons from Chile might represent some of the best guidance for governments that existing evidence and theory offer.

Our findings certainly suggest avenues for further research. First and foremost, we quantify the changes in leverage and aggregate risk that are the result of crisis credit. We presume that there are benefits justifying such an intervention, but we do not measure, quantify, or explicitly model these. A cost-benefit evaluation of crisis credit policies clearly requires such analysis. Related, we allude to, but not explicitly consider, the intertemporal aspects of the trade-offs that governments face between immediately saving firms and potentially slowing growth or recovery. Second, we discuss the distribution of credit across classes of firms for a policy with limited targeting, but we do not analyze the distributional consequences across classes or distributions of workers and/or consumers. Third, our data explicitly cover 
the formal sector, and we have direct risk data only for those firms with borrowing histories. The former constitutes the bulk of the economy in Chile, and the latter absorbs most of the crisis credit. Nevertheless, in many economies, informal sectors and unbanked firms can be quite prominent, which can limit the effectiveness of such programs. Fourth, although we focus on crisis credit when there is an urgency to save firms, the policies we analyze might prove beneficial in non-crisis times to foster credit to underserved sectors. 


\section{References}

Acharya, V. V. and S. Steffen. 2020. The risk of being a fallen angel and the corporate dash for cash in the midst of COVID. Review of Corporate Finance Studies 9(3), 430-471.

Akcigit, U., U. Seven, I. Yarba, and F. Yilmaz. 2021. Firm-level impact of credit guarantees: Evidence from Turkish credit guarantee fund. Central Bank of the Republic of Turkey, Research and Monetary Policy Department Working Paper No.21/10.

Amiram, D. and D. Rabetti. 2020. The relevance of relationship lending in times of crisis. SSRN 3701587.

Autor, D., D. Cho, L. D. Crane, M. Goldar, B. Lutz, J. Montes, W. B. Peterman, D. Ratner, D. Villar, and A. Yildirmaz. 2022. The $\$ 800$ billion paycheck protection program: Where did the money go and why did it go there? Journal of Economic Perspectives 36(2), $55-80$.

Bachas, N., O. S. Kim, and C. Yannelis. 2021. Loan guarantees and credit supply. Journal of Financial Economics 139(3), 872-894.

Balyuk, T., N. R. Prabhala, and M. Puri. 2021. Small bank financing and funding hesitancy in a crisis: Evidence from the paycheck protection program. SSRN 3717259.

Banerjee, R. N. and B. Hofmann. 2020. Corporate zombies: Anatomy and life cycle. BIS Working Papers 882.

Barrot, J.-N., T. Martin, J. Sauvagnat, and B. Valle. 2021. The labor market effects of loan guarantee programs. SSRN 3409349.

Bartik, A. W., Z. B. Cullen, E. L. Glaeser, M. Luca, C. T. Stanton, and A. Sunderam. 2020, July. The targeting and impact of paycheck protection program loans to small businesses. Technical report. NBER Working Paper 27623.

Bennedsen, M., B. Larsen, I. Schmutte, and D. Scur. 2020. Preserving job matches during the COVID-19 pandemic: Firm-level evidence on the role of government aid. Global Labor Organization Discussion Paper Series 588.

Bernanke, B., M. Gertler, and S. Gilchrist. 1999. The financial accelerator in a quantitative business cycle framework. Handbook of Macroeconomics 1(C), 1341-1393.

Brown, J. D. and J. S. Earle. 2017. Finance and growth at the firm level: Evidence from SBA loans. Journal of Finance 72(3), 1039-1080.

Brunnermeier, M. and A. Krishnamurthy. 2020. The macroeconomics of corporate debt. The Review of Corporate Finance Studies 9, 656-665.

Caballero, R. J., T. Hoshi, and A. K. Kashyap. 2008. Zombie lending and depressed restructuring in Japan. American Economic Review 98(5), 1943-77.

Cahuc, P., F. Kramarz, and S. Nevoux. 2018. When short-time work works. CEPR Discussion Paper No. 13041.

Cahuc, P., F. Kramarz, and S. Nevoux. 2021. The heterogeneous impact of short-time work: From saved jobs to windfall effects. CEPR Discussion Paper No. 16168.

Carletti, E., T. Oliviero, M. Pagano, L. Pelizzon, and M. G. Subrahmanyam. 2020. The COVID-19 shock and equity shortfall: Firm-level evidence from Italy. The Review of Corporate Finance Studies 9(3), 534-568.

Central Bank of Chile. 2020. Monetary Policy Report. September.

Cevik, S. and F. Miryugin. 2020. Leverage shocks: Firm-level evidence on debt overhang and investment. IMF Working Papers No. 20/287.

Chari, A., L. Jain, and N. Kulkarni. 2021. The unholy trinity: Regulatory forbearance, stressed banks, and zombie firms. NBER Working Paper 28435.

Chetty, R., J. N. Friedman, N. Hendren, M. Stepner, and The Opportunity Insights Team. 2020. The economic impacts of COVID-19: Evidence from a new public database built 
using private sector data. NBER Working Paper 27431.

Chodorow-Reich, G., O. Darmouni, S. Luck, and M. C. Plosser. 2021. Bank liquidity provision across the firm size distribution. Journal of Financial Economics 144(3), 908-932.

Cirera, X., M. Cruz, E. Davies, A. Grover, L. Iacovone, J. E. Lopez Cordova, D. Medvedev, F. O. Maduko, G. Nayyar, S. Reyes Ortega, and J. Torres. 2021. Policies to support businesses through the COVID-19 shock. World Bank Research Observer 36(1), 41-66.

Cooley, T. F. and V. Quadrini. 2001. Financial markets and firm dynamics. American Economic Review 91(5), 1286-1310.

Core, F. and F. De Marco. 2021. Public guarantees for small businesses in Italy during COVID-19. CEPR Discussion Paper 15799.

Covas, F. and W. Den Haan. 2012. The role of debt and equity finance over the business cycle. Economic Journal 122(565), 1262-1286.

Crawford, G. S., N. Pavanini, and F. Schivardi. 2018. Asymmetric information and imperfect competition in lending markets. American Economic Review 108(7), 1659-1701.

Cros, M., A. Epaulard, and P. Martin. 2021. Will Schumpeter catch COVID-19? CEPR Discussion Paper No. 15834.

Custodio, C., C. Hansman, and D. Mendes. 2021. Information frictions and firm take up of government support: A randomised controlled experiment. Swedish House of Finance Research Paper No. 23-2021.

de Blasio, G., S. De Mitri, A. D'Ignazio, P. Finaldi Russo, and L. Stoppani. 2018. Public guarantees to SME borrowing. Journal of Banking \& Finance 96, $73-86$.

Demmou, L., S. Calligaris, G. Franco, D. Dlugosch, M. A. McGowan, and S. Sakha. 2021. Insolvency and debt overhang following the COVID-19 outbreak: Assessment of risks and policy responses. OECD Economics Department Working Papers No. 1651.

Demmou, L., G. Franco, C. Sara, and D. Dlugosch. 2020. Corporate sector vulnerabilities during the COVID-19 outbreak: Assessment and policy responses. OECD ECOSCOPE.

Didier, T., F. Huneeus, M. Larrain, and S. L. Schmukler. 2021. Financing firms in hibernation during the COVID-19 pandemic. Journal of Financial Stability 53, 100837.

Duchin, R., X. Martin, R. Michaely, and I. Wang. 2021. Concierge treatment from banks: Evidence from the paycheck protection program. Journal of Corporate Finance, 102124.

Díez, F., R. Duval, J. Fan, J. Garrido, S. Kalemli-Özcan, C. Maggi, S. Martinez-Peria, and N. Pierri. 2021. Insolvency prospects among small-and-medium-sized enterprises: Assessment and policy options. IMF Departmental Paper.

Engel, E., C. Gómez, C. Gómez, D. Pardow, and P. Simonetti. 2020. Informe sobre la evolución de la epidemia de COVID-19 en Chile. Centro de Estudios Espacio Público.

Feyen, E., T. Alonso Gispert, T. Kliatskova, and D. S. Mare. 2021. Financial sector policy response to COVID-19 in emerging markets and developing economies. Journal of Banking \& Finance 133, 106184.

Gale, W. G.. 1990. Federal lending and the market for credit. Journal of Public Economics 42(2), $177-193$.

Gale, W. G.. 1991. Economic effects of federal credit programs. American Economic Review 81(1), 133-152.

Gilchrist, S., J. W. Sim, and E. Zakrajšek. 2014. Uncertainty, financial frictions, and investment dynamics. NBER Working Paper No. 20038.

Giupponi, G. and C. Landais. 2018. Subsidizing labor hoarding in recessions: The employment and welfare effects of short time work. CEPR Discussion Paper No. 13310.

Glennon, D. and P. Nigro. 2005. Measuring the default risk of small business loans: A survival analysis approach. Journal of Money, Credit and Banking 37(5), 923-947. 
Gonzalez-Uribe, J. and S. Wang. 2021. The real effects of small-firm credit guarantees during recessions. SSRN 3382280.

Gourinchas, P.-O., S. Kalemli-Ozcan, V. Penciakova, and N. Sander. 2021. COVID-19 and SME failures. NBER Working Paper 27877.

Granja, J., C. Makridis, C. Yannelis, and E. Zwick. 2020. Did the paycheck protection program hit the target? NBER Working Paper 27095.

Greenwald, D. L., J. Krainer, and P. Paul. 2021. The credit line channel. Federal Reserve Bank of San Francisco Working Paper 2020-26.

Hijzen, A. and D. Venn. 2011. The role of short-time work schemes during the 2008-09 recession. OECD Social, Employment and Migration Working Papers 115.

Hubbard, R. G. and M. R. Strain. 2020. Has the paycheck protection program succeeded? Working Paper 28032, NBER.

Jiménez, G., J.-L. Peydró, R. Repullo, and J. Saurina. 2018. Burning money? Government lending in a credit crunch. CEPR Discussion Paper No. 13267.

Kalemli-Ozcan, S., L. Laeven, and D. Moreno. 2019. Debt overhang, rollover risk, and corporate investment: Evidence from the European crisis. European Central Bank Working Paper 2241.

Keller, F. and B. Zoller-Rydzek. 2020. COVID-19: Guaranteed loans and zombie firms. CESifo Economic Studies 66(4), 322-364.

Kopp, D. and M. Siegenthaler. 2021. Short-time work and unemployment in and after the great recession. Journal of the European Economic Association 19(4), 2283-2321.

Lelarge, C., D. Sraer, and D. Thesmar. 2010. Entrepreneurship and credit constraints: Evidence from a french loan guarantee program. In J. Lerner and A. Schoar (Eds.), International Differences in Entrepreneurship, Chapter 8, 243-273. University of Chicago Press.

Li, L. and P. E. Strahan. 2021. Who supplies PPP loans (and does it matter)? Banks, relationships, and the COVID crisis. Journal of Financial and Quantitative Analysis 56(7), 2411-2438.

Li, L., P. E. Strahan, and S. Zhang. 2020. Banks as lenders of first resort: Evidence from the COVID-19 crisis. Review of Corporate Finance Studies 9(3), 472-500.

Mullins, W. and P. Toro. 2018. Credit guarantees and new bank relationships. Central Bank of Chile Working Paper 820.

OECD. 2017. Evaluating publicly supported credit guarantee programmes for SMEs.

Reinhart, C. M.. 2022. From Health Crisis to Financial Distress. IMF Economic Review 70 (1), $4-31$.

Schivardi, F., E. Sette, and G. Tabellini. 2017. Credit misallocation during the European financial crisis. BIS Working Papers 669.

Smith, B.. 1983. Limited information, credit rationing, and optimal government lending policy. American Economic Review 73(3), 305-318.

Xiao, J.. 2020. Borrowing to save and investment dynamics. SSRN 3478294. 


\section{Appendix A: Sharing Unexpected Risk}

To cover unexpected credit risk, banks hold capital in their balance sheets. Bank regulation requires banks to have a minimum capital adequacy ratio, defined as capital expressed as a percentage of its risk-weighted credit exposures. ${ }^{46}$ During 2020, the capital adequacy ratio of the banking industry in Chile increases by 1.8 percentage points, from $12.8 \%$ in December 2019 to 14.7\% in December 2020 (Online Appendix Table A10). This is the result of both an increase in bank capital (the numerator of the ratio) and a decrease in risk-weighted assets (the denominator of the ratio). Regarding the numerator, bank capital rises by $10 \%$, from US $\$ 37,514$ million to US $\$ 41,275$ million. This rise is driven, in part, by an increase in loan-loss provisions above the legal minimum. Banks constitute additional provisions that count as bank capital to cover for unexpected credit risks that cannot be easily identified.

The transfer of unexpected credit risk from banks to the government effectively reduces banks' risk-weighted assets, the denominator of the capital adequacy ratio. Loans are classified in five risk categories. To reflect the government's backing of unexpected risk, the CMF allows banks to reclassify the fraction of the loans guaranteed by the government to the risk category 2 (with a capital charge of only 10\%), from the previous typical risk weight asset category 5 (with a capital charge of $100 \%$ ). Thus, banks reclassify US $\$ 10$ billion worth of public guaranteed loans. Risk-weighted assets in category 5 decrease by US $\$ 10$ billion, while those in category 2 increase by US $\$ 1$ billion. This reduces the risk-weighted assets by US $\$ 9$ billion, out of a total reduction of almost US $\$ 11$ billion during 2020 . In sum, the sharing of unexpected credit risk between banks and the government improves the banks' solvency measures.

Another way in which banks and the government as a whole share risk is through the provision of liquidity support to banks. The Central Bank of Chile complements the credit program established by the Ministry of Finance by offering liquidity facilities to banks at a low interest rate. ${ }^{47}$ This financing is allocated conditional on the banks actually lending to firms. Banks do not have to raise funds in capital markets or crowd out other loans. Implicitly, the government takes the risk in case the program fails. Banks use this financing as needed, and the allocation of these funds is mostly based on their demand for it. In fact, the banks that grant more loans under the credit guarantee program use the central bank liquidity facility more intensively (Online Appendix Figure A5).

\footnotetext{
${ }^{46}$ Assets with higher unexpected risk have higher capital charges, requiring more capital. Basel III regulation in Chile requires banks to comply with this rule by maintaining a capital adequacy ratio above $8 \%$.

${ }^{47}$ The liquidity facility of the Central Bank of Chile is named the Facility of Credit Conditional on Lending Increase (FCIC).
} 
Figure 1

Reach of Public Programs

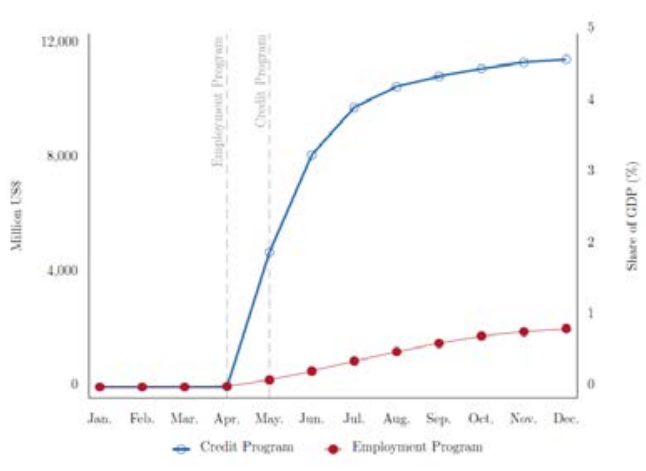

(A) Size of Public Programs

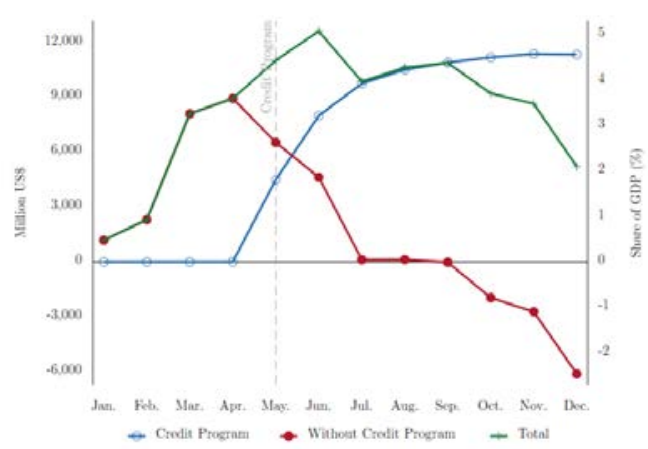

(C) Total Corporate Credit Granted: Guaranteed and Non-Guaranteed Credit

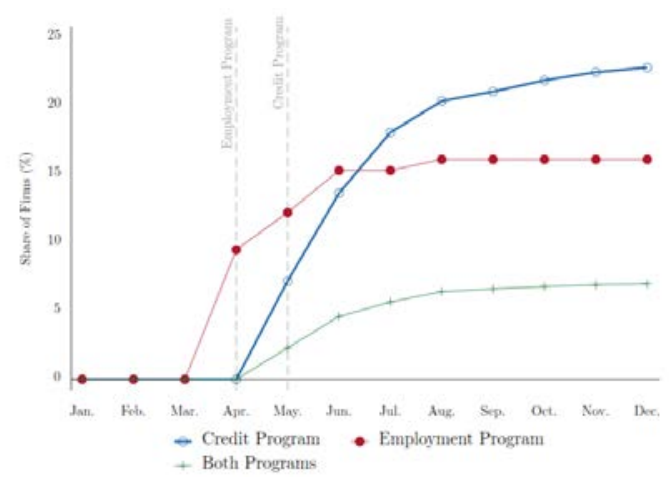

(B) Share of Firms Using Public Programs

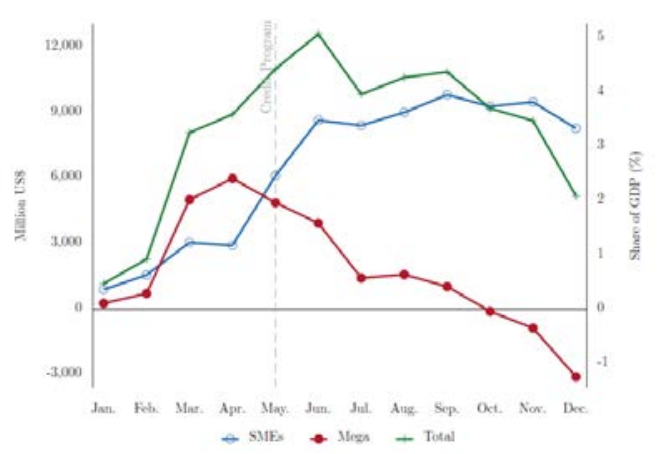

(D) Total Corporate Credit Granted by Firm Size

This figure plots the size of the public programs implemented in Chile, the cumulative share of firms using public programs during 2020, and the cumulative corporate credit granted in Chile during 2020. The top-left panel plots the size in million US\$ (left axis) and as a share of GDP (right axis) and considers natural persons and formal firms. The top-right panel displays the share of firms using the credit program, the employment program, and both programs by the end of each month during 2020. The share of firms is calculated relative to the number of eligible firms for each program from the active firms sample. The bottom-left and bottom-right panels plot amounts in million US\$ (left axis) and as a share of GDP (right axis) and consider natural persons and formal firms. Cumulative credit is equal to the difference between the credit stock in a given month of 2020 and the credit stock in December 2019. The bottom-left panel decomposes total credit into credit guaranteed under the credit program and credit outside the program. The bottom-right panel decomposes total credit into credit granted to SMEs and large firms (which are eligible for the credit program) and to mega firms (ineligible for the program). The dotted vertical lines show the month in which each program is implemented. 
Figure 2

Simulated Model
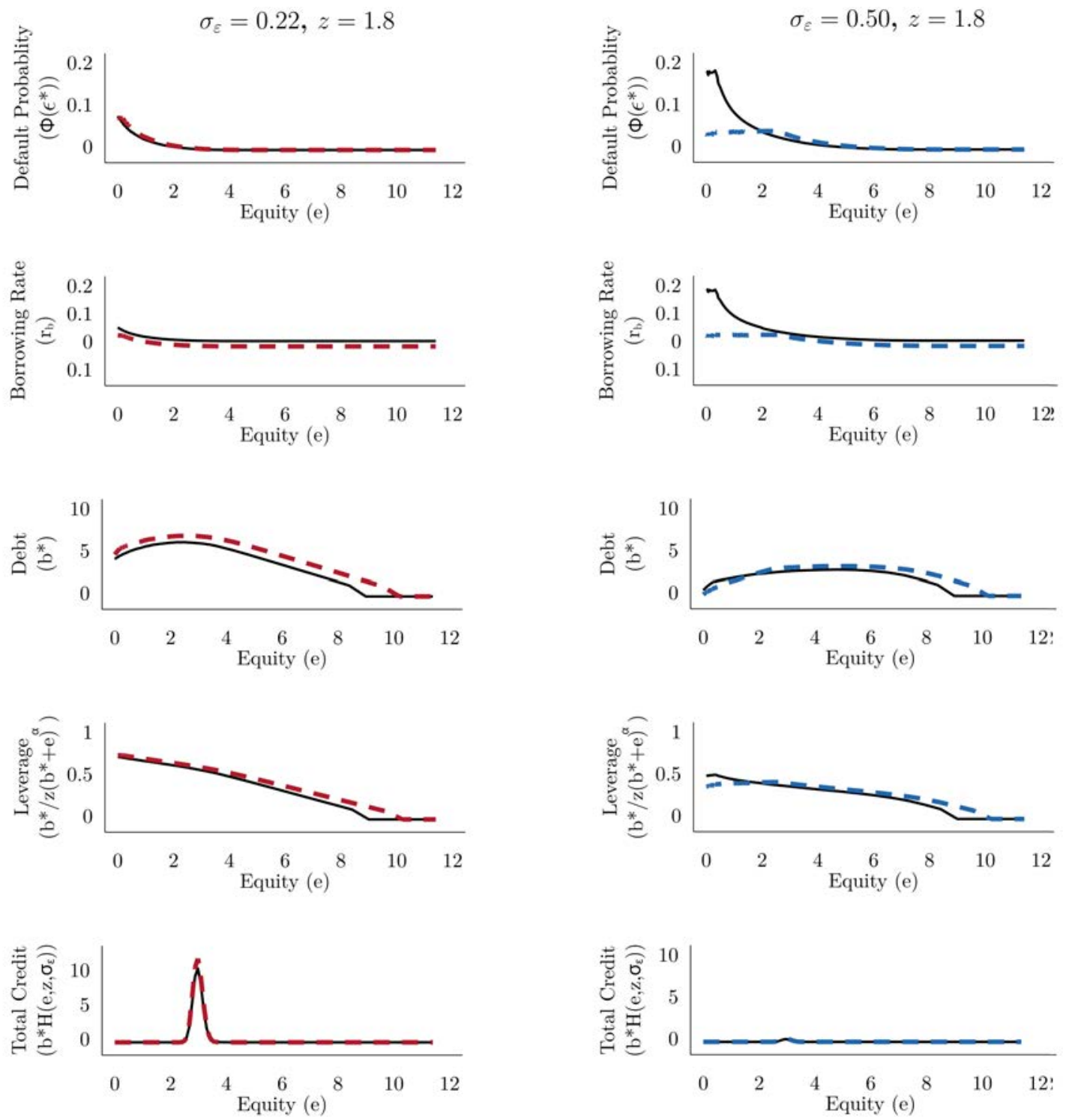

This figure shows borrowing outcomes (y-axis) as a function of equity (x-axis) for firms with two different values of uncertainty (or equity-independent risk), $\sigma$. Both panels are for a firm with moderate productivity, $z=1.8$, but the panels on the left have a moderate level of uncertainty, $\sigma=0.22$, while the panels on the right are for a higher uncertainty, $\sigma=0.50$. The solid dark line illustrates the results for a firm in the benchmark banking system. The dashed line illustrates the results under the counterfactual policy credit program. 
Table 1

Default Probability Model

\begin{tabular}{|c|c|c|c|c|c|c|c|c|}
\hline & $(1)$ & $(2)$ & $(3)$ & $(4)$ & $(5)$ & $(6)$ & $(7)$ & $(8)$ \\
\hline \multicolumn{9}{|l|}{ Panel A: Probit Estimation } \\
\hline Log(Net Worth) & $\begin{array}{c}-0.011 \\
(0.001)\end{array}$ & $\begin{array}{c}-0.010 \\
(0.001)\end{array}$ & $\begin{array}{c}-0.010 \\
(0.001)\end{array}$ & $\begin{array}{c}-0.010 \\
(0.001)\end{array}$ & $\begin{array}{c}-0.009 \\
(0.001)\end{array}$ & $\begin{array}{c}-0.009 \\
(0.001)\end{array}$ & $\begin{array}{c}-0.008 \\
(0.001)\end{array}$ & $\begin{array}{c}-0.009 \\
(0.001)\end{array}$ \\
\hline Log(Value Added/Number of Workers) & $\begin{array}{c}-0.021 \\
(0.001)\end{array}$ & $\begin{array}{c}-0.020 \\
(0.001)\end{array}$ & $\begin{array}{c}-0.018 \\
(0.001)\end{array}$ & $\begin{array}{c}-0.018 \\
(0.001)\end{array}$ & $\begin{array}{c}-0.019 \\
(0.001)\end{array}$ & $\begin{array}{c}-0.019 \\
(0.001)\end{array}$ & $\begin{array}{c}-0.017 \\
(0.001)\end{array}$ & $\begin{array}{c}-0.017 \\
(0.001)\end{array}$ \\
\hline Firm Age & $\begin{array}{c}-0.001 \\
(0.000)\end{array}$ & $\begin{array}{c}-0.001 \\
(0.000)\end{array}$ & $\begin{array}{c}-0.001 \\
(0.000)\end{array}$ & $\begin{array}{c}-0.001 \\
(0.000)\end{array}$ & $\begin{array}{c}-0.002 \\
(0.000)\end{array}$ & $\begin{array}{c}-0.002 \\
(0.000)\end{array}$ & $\begin{array}{c}-0.002 \\
(0.000)\end{array}$ & $\begin{array}{c}-0.002 \\
(0.000)\end{array}$ \\
\hline Log(Wage Bill) & $\begin{array}{c}-0.009 \\
(0.001)\end{array}$ & $\begin{array}{c}-0.009 \\
(0.001)\end{array}$ & $\begin{array}{c}-0.008 \\
(0.001)\end{array}$ & $\begin{array}{c}-0.008 \\
(0.001)\end{array}$ & $\begin{array}{c}-0.008 \\
(0.001)\end{array}$ & $\begin{array}{c}-0.008 \\
(0.001)\end{array}$ & $\begin{array}{c}-0.007 \\
(0.001)\end{array}$ & $\begin{array}{c}-0.007 \\
(0.001)\end{array}$ \\
\hline Log(Annual Sales) & $\begin{array}{c}0.007 \\
(0.001)\end{array}$ & $\begin{array}{c}0.006 \\
(0.001)\end{array}$ & $\begin{array}{c}0.002 \\
(0.001)\end{array}$ & $\begin{array}{c}0.002 \\
(0.001)\end{array}$ & $\begin{array}{c}0.000 \\
(0.001)\end{array}$ & $\begin{array}{c}0.000 \\
(0.001)\end{array}$ & $\begin{array}{c}-0.003 \\
(0.001)\end{array}$ & $\begin{array}{c}-0.003 \\
(0.001)\end{array}$ \\
\hline Log(Credit Stock) & & & & & $\begin{array}{c}0.013 \\
(0.001)\end{array}$ & $\begin{array}{c}0.013 \\
(0.001)\end{array}$ & $\begin{array}{c}0.013 \\
(0.001)\end{array}$ & $\begin{array}{c}0.013 \\
(0.001)\end{array}$ \\
\hline Spread Ex-Ante & & & & & $\begin{array}{c}0.003 \\
(0.000)\end{array}$ & $\begin{array}{c}0.003 \\
(0.000)\end{array}$ & $\begin{array}{c}0.003 \\
(0.000)\end{array}$ & $\begin{array}{c}0.003 \\
(0.000)\end{array}$ \\
\hline Dependent Variable Mean & 0.088 & 0.088 & 0.088 & 0.088 & 0.088 & 0.088 & 0.088 & 0.088 \\
\hline Dependent Variable Std. Dev. & 0.284 & 0.284 & 0.284 & 0.284 & 0.284 & 0.284 & 0.284 & 0.284 \\
\hline Number of Firms & 96,424 & 96,424 & 96,424 & 96,424 & 96,424 & 96,424 & 96,424 & 96,424 \\
\hline $\mathrm{R}^{2}$ & 0.051 & 0.061 & 0.064 & 0.073 & 0.095 & 0.103 & 0.104 & 0.112 \\
\hline Industry FE & No & No & Yes & Yes & No & No & Yes & Yes \\
\hline Municipality FE & No & Yes & No & Yes & No & Yes & No & Yes \\
\hline \multicolumn{9}{|l|}{ Panel B: Predicted Default Probability } \\
\hline Banked Firms & 0.088 & 0.088 & 0.088 & 0.088 & 0.089 & 0.089 & 0.089 & 0.089 \\
\hline Unbanked Firms & 0.113 & 0.113 & 0.107 & 0.107 & & & & \\
\hline
\end{tabular}

This table reports probit estimations of the probability of a banked firm defaulting on a loan on a set of firm-level characteristics (Panel A) and the resulting predicted default probabilities for banked and unbanked firms (Panel B) for the default model sample. The dependent variable is a dummy equal to one if the firm defaults on a loan during 2019 (has payment past due over 90 days) and zero otherwise. All explanatory variables are calculated as of December 2018. Given that the data on firms' net worth are not available for all firms, all specifications include an unreported dummy variable equal to one if the data for the firm's net worth are missing and zero otherwise. Banked firms are those that either have bank credit outstanding in December 2019 or receive a bank loan over the period 2012-2019. Columns 1-4 include real characteristics, and Columns 5-8 add financial characteristics. Columns 1-8 include different sets of fixed effects (FE). Standard errors, shown in parentheses, are clustered at the industry and municipality level.

Table 2

Probability of Firms Using Public Programs

\begin{tabular}{|c|c|c|c|c|c|c|c|c|}
\hline & \multicolumn{6}{|c|}{ Credit Program } & \multirow{2}{*}{\multicolumn{2}{|c|}{$\begin{array}{c}\text { Employment Program } \\
\text { Use }\end{array}$}} \\
\hline & \multicolumn{2}{|c|}{ Use } & \multicolumn{2}{|c|}{ Applications } & \multicolumn{2}{|c|}{ Approvals } & & \\
\hline & $(1)$ & $(2)$ & $(3)$ & $(4)$ & $(5)$ & $(6)$ & $(7)$ & $(8)$ \\
\hline Risk & $\begin{array}{c}0.647 \\
(0.043)\end{array}$ & $\begin{array}{c}0.337 \\
(0.034)\end{array}$ & $\begin{array}{c}0.845 \\
(0.048)\end{array}$ & $\begin{array}{c}0.538 \\
(0.035)\end{array}$ & $\begin{array}{c}-0.222 \\
(0.018)\end{array}$ & $\begin{array}{c}-0.257 \\
(0.021)\end{array}$ & $\begin{array}{c}0.084 \\
(0.025)\end{array}$ & $\begin{array}{l}-0.016 \\
(0.024)\end{array}$ \\
\hline Increase in Sales Dummy & $\begin{array}{c}0.216 \\
(0.008)\end{array}$ & $\begin{array}{c}0.195 \\
(0.008)\end{array}$ & $\begin{array}{l}0.206 \\
(0.007)\end{array}$ & $\begin{array}{c}0.186 \\
(0.008)\end{array}$ & $\begin{array}{c}0.019 \\
(0.006)\end{array}$ & $\begin{array}{c}0.019 \\
(0.006)\end{array}$ & $\begin{array}{c}0.046 \\
(0.007)\end{array}$ & $\begin{array}{c}0.053 \\
(0.007)\end{array}$ \\
\hline Decrease in Sales Dummy & $\begin{array}{c}0.210 \\
(0.008)\end{array}$ & $\begin{array}{c}0.193 \\
(0.008)\end{array}$ & $\begin{array}{c}0.204 \\
(0.007)\end{array}$ & $\begin{array}{c}0.188 \\
(0.007)\end{array}$ & $\begin{array}{c}0.019 \\
(0.006)\end{array}$ & $\begin{array}{c}0.019 \\
(0.006)\end{array}$ & $\begin{array}{c}0.119 \\
(0.007)\end{array}$ & $\begin{array}{c}0.112 \\
(0.007)\end{array}$ \\
\hline Use Employment Program & $\begin{array}{c}0.098 \\
(0.005)\end{array}$ & $\begin{array}{c}0.095 \\
(0.005)\end{array}$ & $\begin{array}{c}0.122 \\
(0.005)\end{array}$ & $\begin{array}{c}0.117 \\
(0.005)\end{array}$ & $\begin{array}{c}-0.011 \\
(0.004)\end{array}$ & $\begin{array}{r}-0.010 \\
(0.004)\end{array}$ & & \\
\hline Use Credit Program & & & & & & & $\begin{array}{c}0.059 \\
(0.003)\end{array}$ & $\begin{array}{c}0.056 \\
(0.003)\end{array}$ \\
\hline Dependent Variable Mean & 0.505 & 0.505 & 0.649 & 0.649 & 0.920 & 0.918 & 0.183 & 0.185 \\
\hline Dependent Variable Std. Dev. & 0.500 & 0.500 & 0.477 & 0.477 & 0.272 & 0.275 & 0.387 & 0.389 \\
\hline Number of Firms & 62,927 & 62,871 & 62,927 & 62,848 & 36,701 & 35,918 & 62,927 & 62,102 \\
\hline $\mathrm{R}^{2}$ & 0.020 & 0.045 & 0.032 & 0.061 & 0.008 & 0.033 & 0.019 & 0.081 \\
\hline Industry FE & No & Yes & No & Yes & No & Yes & No & Yes \\
\hline Municipality FE & No & Yes & No & Yes & No & Yes & No & Yes \\
\hline $\begin{array}{l}\text { Predicted Default Probability } \\
\text { Banked Firms }\end{array}$ & 0.084 & 0.084 & 0.084 & 0.084 & 0.090 & 0.090 & 0.084 & 0.084 \\
\hline
\end{tabular}

This table reports probit estimations of the probability of a banked firm using a government program on a set of firm-level characteristics. Banked firms are those that either have bank credit outstanding in December 2019 or receive a bank loan over the period 2012-2019. The dependent variable is equal to one if the firm participates in the credit program (Columns 1-4),is equal to one if the firm participates in the employment program (Columns 5-8), and is zero otherwise. Risk corresponds to the fitted values of the regression specification reported in Table 1, Column 8. Increase (decrease) in sales dummy is equal to one if the firm experiences a positive (negative) variation in sales between February 2020 and April 2020. Use credit program and employment program are dummy variables equal to one for program participation and is zero otherwise. The table uses the banked firms of the credit program eligible firms sample. Some observations are dropped when estimating the model with fixed effects. Standard errors, shown in parentheses, are clustered at the industry and municipality level. 
Table 3

Firm Indebtedness and Use of Public Programs

\begin{tabular}{|c|c|c|c|c|c|c|}
\hline & \multicolumn{2}{|c|}{$\Delta$ D Debt / Sales (2019) } & \multicolumn{2}{|c|}{$\begin{array}{c}\Delta \text { Guaranteed Debt / } \\
\text { Sales (2019) }\end{array}$} & \multicolumn{2}{|c|}{$\begin{array}{c}\Delta \text { Non-Guaranteed Debt } \\
\text { Sales }(2019)\end{array}$} \\
\hline & $\begin{array}{c}(1) \\
\text { Banked }\end{array}$ & $\begin{array}{c}(2) \\
\text { Unbanked }\end{array}$ & $\begin{array}{c}(3) \\
\text { Banked }\end{array}$ & $\begin{array}{c}(4) \\
\text { Unbanked }\end{array}$ & $\begin{array}{c}(5) \\
\text { Banked }\end{array}$ & $\begin{array}{c}(6) \\
\text { Unbanked }\end{array}$ \\
\hline Use Credit Program & $\begin{array}{c}0.145 \\
(0.001)\end{array}$ & $\begin{array}{l}0.130 \\
(0.001)\end{array}$ & $\begin{array}{c}0.139 \\
(0.000)\end{array}$ & $\begin{array}{c}0.118 \\
(0.001)\end{array}$ & $\begin{array}{c}0.008 \\
(0.001)\end{array}$ & $\begin{array}{c}0.011 \\
(0.001)\end{array}$ \\
\hline Use Employment Program & $\begin{array}{c}0.008 \\
(0.002)\end{array}$ & $\begin{array}{c}0.002 \\
(0.001)\end{array}$ & $\begin{array}{c}0.001 \\
(0.000)\end{array}$ & $\begin{array}{c}0.000 \\
(0.000)\end{array}$ & $\begin{array}{c}0.008 \\
(0.002)\end{array}$ & $\begin{array}{c}0.001 \\
(0.001)\end{array}$ \\
\hline $\begin{array}{l}\text { Use Credit Program } \\
\times \text { Employment Program }\end{array}$ & $\begin{array}{r}-0.013 \\
(0.003)\end{array}$ & $\begin{array}{c}-0.016 \\
(0.003)\end{array}$ & $\begin{array}{c}-0.003 \\
(0.001)\end{array}$ & $\begin{array}{c}-0.009 \\
(0.002)\end{array}$ & $\begin{array}{c}-0.010 \\
(0.003)\end{array}$ & $\begin{array}{l}-0.006 \\
(0.001)\end{array}$ \\
\hline Increase in Sales Dummy & $\begin{array}{c}0.021 \\
(0.003)\end{array}$ & $\begin{array}{c}0.004 \\
(0.001)\end{array}$ & $\begin{array}{c}-0.001 \\
(0.001)\end{array}$ & $\begin{array}{c}0.001 \\
(0.000)\end{array}$ & $\begin{array}{c}0.023 \\
(0.003)\end{array}$ & $\begin{array}{c}0.002 \\
(0.001)\end{array}$ \\
\hline Decrease in Sales Dummy & $\begin{array}{c}0.017 \\
(0.003)\end{array}$ & $\begin{array}{c}0.002 \\
(0.001)\end{array}$ & $\begin{array}{c}-0.002 \\
(0.001)\end{array}$ & $\begin{array}{c}0.000 \\
(0.000)\end{array}$ & $\begin{array}{c}0.021 \\
(0.003)\end{array}$ & $\begin{array}{c}0.002 \\
(0.000)\end{array}$ \\
\hline Dependent Variable Mean & 0.054 & 0.028 & 0.070 & 0.020 & -0.018 & 0.007 \\
\hline Dependent Variable Std. Dev. & 0.172 & 0.082 & 0.087 & 0.055 & 0.140 & 0.045 \\
\hline Number of Firms & 62,927 & 51,679 & 62,927 & 51,679 & 62,927 & 51,679 \\
\hline $\mathrm{R}^{2}$ & 0.191 & 0.359 & 0.628 & 0.645 & 0.021 & 0.020 \\
\hline Industry FE and Municipality FE & Yes & Yes & Yes & Yes & Yes & Yes \\
\hline
\end{tabular}

This table reports linear regressions of the change in firms' leverage on a set of firm-level characteristics, separately for banked and unbanked firms, for the credit program eligible firms sample. Banked firms are those that either have bank credit outstanding in December 2019 or receive a bank loan over the period 2012-2019. The dependent variable is the change in the credit stock between December 2020 and December 2019, relative to 2019 sales. Use credit program and employment program are dummy variables for program participation. Increase (decrease) in sales is a dummy variable equal to one if the firm experiences a positive (negative) variation in sales between February 2020 and April 2020 and is zero otherwise. All columns include industry and municipality fixed effects. Standard errors, shown in parentheses, are clustered at the industry and municipality level. For each dependent variable, observations in the top and bottom $1 \%$ of the distribution are dropped.

Table 4

Firm Indebtedness and Risk among Credit Program Users

\begin{tabular}{|c|c|c|c|c|}
\hline & \multicolumn{2}{|c|}{$\begin{array}{c}\Delta \text { Guaranteed Debt / } \\
\text { Sales (2019) }\end{array}$} & \multicolumn{2}{|c|}{$\begin{array}{c}\Delta \text { Non-Guaranteed Debt } \\
\text { Sales }(2019)\end{array}$} \\
\hline & $\begin{array}{c}(1) \\
\text { Banked }\end{array}$ & $\begin{array}{c}(2) \\
\text { Unbanked }\end{array}$ & $\begin{array}{c}(3) \\
\text { Banked }\end{array}$ & $\begin{array}{c}(4) \\
\text { Unbanked }\end{array}$ \\
\hline Risk & $\begin{array}{c}0.095 \\
(0.007)\end{array}$ & $\begin{array}{c}0.171 \\
(0.019)\end{array}$ & $\begin{array}{r}-0.065 \\
(0.011)\end{array}$ & $\begin{array}{r}-0.020 \\
(0.014)\end{array}$ \\
\hline Increase in Sales Dummy & $\begin{array}{r}-0.003 \\
(0.002)\end{array}$ & $\begin{array}{c}0.010 \\
(0.004)\end{array}$ & $\begin{array}{c}0.007 \\
(0.004)\end{array}$ & $\begin{array}{c}0.006 \\
(0.003)\end{array}$ \\
\hline Decrease in Sales Dummy & $\begin{array}{r}-0.007 \\
(0.002)\end{array}$ & $\begin{array}{c}0.004 \\
(0.004)\end{array}$ & $\begin{array}{c}0.004 \\
(0.004)\end{array}$ & $\begin{array}{c}0.004 \\
(0.003)\end{array}$ \\
\hline Dependent Variable Mean & 0.138 & 0.116 & -0.013 & 0.015 \\
\hline Dependent Variable Std. Dev. & 0.076 & 0.079 & 0.128 & 0.062 \\
\hline Number of Firms & 31,782 & 9,119 & 31,782 & 9,119 \\
\hline $\mathrm{R}^{2}$ & 0.033 & 0.091 & 0.029 & 0.066 \\
\hline Industry FE and Municipality FE & Yes & Yes & Yes & Yes \\
\hline
\end{tabular}

This table reports linear regressions of the change in firms' guaranteed and non-guaranteed debt on a set of firm-level characteristics among firms that use the credit program, separately for banked and unbanked firms, for the credit program users sample. Banked firms are those that either have bank credit outstanding in December 2019 or receive a bank loan over the period 2012-2019. The dependent variable in Columns 1-2 (3-4) is the change in the stock of public guaranteed (non-guaranteed) debt between December 2020 and December 2019, relative to 2019 sales. Risk corresponds to the fitted values of the regression specifications reported in Columns 4 and 8 of Table 1 for unbanked and banked firms, respectively. Increase (decrease) in sales dummy is equal to one if the firm experiences a positive (negative) variation in sales between February 2020 and April 2020 and is zero otherwise. All columns include industry and municipality fixed effects. Bootstrapped standard errors, shown in parentheses, are clustered at the industry and municipality level. For each dependent variable, observations in the top and bottom $1 \%$ of the distribution are dropped. 
Table 5

Changes in Aggregate Firm Indebtedness

\begin{tabular}{|c|c|c|c|}
\hline & $\begin{array}{c}\Delta \text { Debt / } \\
\text { Sales (2019) } \\
(1) \\
\text { Within } \\
\text { Change } \\
\text { (p.p.) } \\
0.4\end{array}$ & $\begin{array}{c}(2) \\
\text { Weights } \\
(\%)\end{array}$ & $\begin{array}{c}\Delta \text { Debt / } \\
\text { Sales }(2019) \\
(3) \\
\text { Group } \\
\text { Change } \\
(=(1) \times(2)) \\
\text { (p.p. })\end{array}$ \\
\hline \multicolumn{4}{|c|}{ Panel A: Risk Groups (Credit Program Users) } \\
\hline High Risk & 10.70 & 7.1 & 0.11 \\
\hline Medium Risk & 9.29 & 12.7 & 0.16 \\
\hline Medium-Low Risk & 9.70 & 19.3 & 0.26 \\
\hline Low Risk & 9.18 & 41.2 & 0.53 \\
\hline No Risk Data & 10.75 & 19.7 & 0.29 \\
\hline Total & & 100.0 & 1.35 \\
\hline \multicolumn{4}{|c|}{ Panel B: Use of the Credit Program (Active Firms) } \\
\hline Users & 9.71 & 13.9 & 1.35 \\
\hline Non-Users & -1.06 & 86.1 & -0.91 \\
\hline Total & & 100.0 & 0.44 \\
\hline \multicolumn{4}{|c|}{ Panel C: Risk Groups (Active Firms) } \\
\hline High Risk & 4.34 & 1.8 & 0.08 \\
\hline Medium Risk & 3.18 & 4.1 & 0.13 \\
\hline Medium-Low Risk & 2.26 & 8.4 & 0.19 \\
\hline Low Risk & -0.15 & 59.3 & -0.09 \\
\hline No Risk Data & 0.48 & 26.4 & 0.13 \\
\hline Total & & 100.0 & 0.44 \\
\hline
\end{tabular}

This table shows the contribution of different groups of firms to the aggregate change in firm indebtedness for the credit program users (within the active firms sample) (Panel A) and the active firms sample (Panel B). Change in firm indebtedness is measured as the difference in the stock of credit between December 2020 and December 2019, relative to 2019 sales. Panel A divides firms according to their level of risk among credit program users. Panel B divides firms between credit program users and non-users. Panel C divides firms according to their level of risk, considering all active firms (including users and non-users). High, medium, medium-low, and low risk groups are all equally sized and constructed by using the fitted values of the regression specifications reported in Table 1, Columns 4 and 8. Firms with no available data on their risk-fitted values are included in the residual group (no risk data). Column 1 shows the change in percentage points within each group. Column 2 shows the share of sales that each group category accounts for in the different samples. Column 3 is the product of Columns 1 and 2. 
Table 6

Expected Loss for the Banking Industry and the Government

\begin{tabular}{|c|c|c|c|c|c|c|c|c|c|c|}
\hline & $\begin{array}{c}(1) \\
\text { Total Credit } \\
\text { Program } \\
\text { (Million US\$) }\end{array}$ & $\begin{array}{c}(2) \\
\text { Total Credit } \\
\text { Program/GDP } \\
(\%)\end{array}$ & $\begin{array}{c}(3) \\
\text { Share of } \\
\text { Credit } \\
\text { Program } \\
(\%)\end{array}$ & $\begin{array}{c}(4) \\
\text { Default } \\
\text { Probability } \\
(\%)\end{array}$ & $\begin{array}{c}(5) \\
\text { Guarantee } \\
(\%)\end{array}$ & $\begin{array}{c}(6) \\
\text { Deductible } \\
(\%)\end{array}$ & $\begin{array}{c}(7) \\
\text { Effective } \\
\text { Guarantee } \\
(\%)\end{array}$ & $\begin{array}{c}(8) \\
\text { Expected } \\
\text { Loss/GDP } \\
(=(2) \times(4)) \\
(\%)\end{array}$ & $\begin{array}{c}(9) \\
\text { Government's } \\
\text { Expected } \\
\text { Loss/GDP } \\
(=(7) \times(8)) \\
(\%) \\
\end{array}$ & $\begin{array}{c}(10) \\
\text { Banks' } \\
\text { Expected } \\
\text { Loss/GDP } \\
(=(8)-(9)) \\
(\%)\end{array}$ \\
\hline \multicolumn{11}{|l|}{ Panel A: Risk Groups, Formal Firms } \\
\hline High Risk & 606 & 0.2 & 7 & 18.17 & 82.5 & 4.4 & 35.8 & 0.04 & 0.01 & 0.03 \\
\hline Medium Risk & 1,086 & 0.4 & 12 & 9.86 & 79.9 & 4.0 & 32.3 & 0.04 & 0.01 & 0.03 \\
\hline Medium-Low Risk & 1,868 & 0.8 & 21 & 5.68 & 77.0 & 3.5 & 28.2 & 0.05 & 0.01 & 0.04 \\
\hline Low Risk & 3,975 & 1.6 & 44 & 2.05 & 72.1 & 3.0 & 21.1 & 0.03 & 0.01 & 0.03 \\
\hline No Risk Data & 1,489 & 0.6 & 17 & 18.17 & 82.5 & 4.4 & 35.8 & 0.11 & 0.04 & 0.07 \\
\hline Total: Formal Firms & 9,022 & 3.6 & 100 & 7.48 & 76.5 & 3.5 & 27.3 & 0.27 & 0.09 & 0.18 \\
\hline \multicolumn{11}{|l|}{ Panel B: Formal Firms + Natural Persons } \\
\hline Total Formal Firms & 9,022 & 3.6 & 79 & 7.48 & 76.5 & 3.5 & 27.3 & 0.27 & 0.09 & 0.18 \\
\hline Natural Persons & 2,445 & 1.0 & 21 & 18.17 & 82.5 & 4.4 & 35.8 & 0.17 & 0.06 & 0.11 \\
\hline Total: Formal Firms + Natural Persons & 11,467 & 4.6 & 100 & 9.56 & 77.6 & 3.7 & 29.1 & 0.44 & 0.15 & 0.29 \\
\hline
\end{tabular}

This table shows the distribution of the aggregate expected loss borne by the government and the banking system as a result of the credit program, for natural persons and the formal firms sample. Panel A reports statistics across the firms' risk distribution. Panel B reports statistics separately for formal firms and natural persons. Column 1 shows the total amount of guaranteed credit in dollar terms, and Column 2 normalizes first-loss deductible for each category, while Column 7 shows the effective guarantee after taking into account the deductible. Columns 8,9 , and 10 show, for each category, the total expected loss as share of GDP (Column 2 times Column 4), the fraction borne by the government (Column 7 times Column 8), and the fraction borne by the banking sector (Column 8 minus Column 9), respectively. Values in Columns 4-7 are weighted by the total amount of guaranteed credit granted to each firm as a share of the total guaranteed credit granted to all the firms within its category. Totals by panel reported in Columns $4-7$ are calculated as the sum of the product of each category's statistic by its relative weight (Column 3). Firms are classified across risk categories based on the distribution quartiles of the fitted values of the regression specifications reported in Table 1, Columns 4 and 8 . Firms with missing risk category are assigned the risk from the high-risk category. 
Table 7

Probability of Different Firms Getting Approval for the Credit Program

\begin{tabular}{lcccc}
\hline \hline & \multicolumn{4}{c}{ Credit Program Approvals } \\
\cline { 2 - 5 } & $(1)$ & $(2)$ & $(3)$ & $(4)$ \\
& All & Small & Medium & Large \\
& Firms & Firms & Firms & Firms \\
\cline { 2 - 5 } Risk & & & & \\
& -0.257 & -0.246 & -0.439 & -0.755 \\
Increase in Sales Dummy & $(0.021)$ & $(0.025)$ & $(0.082)$ & $(0.238)$ \\
& 0.019 & 0.022 & 0.008 & -0.010 \\
Decrease in Sales Dummy & $(0.006)$ & $(0.008)$ & $(0.019)$ & $(0.035)$ \\
& 0.019 & 0.022 & 0.005 & 0.002 \\
Use Employment Program & $(0.006)$ & $(0.007)$ & $(0.019)$ & $(0.034)$ \\
& -0.010 & -0.008 & -0.015 & -0.026 \\
& $(0.004)$ & $(0.004)$ & $(0.008)$ & $(0.020)$ \\
Dependent Variable Mean & & & & \\
Dependent Variable Std. Dev. & 0.918 & 0.913 & 0.918 & 0.902 \\
Number of Firms & 0.275 & 0.282 & 0.275 & 0.298 \\
$\mathrm{R}^{2}$ & 35,918 & 26,623 & 5,916 & 1,392 \\
Industry FE and Municipality FE & 0.033 & 0.036 & 0.082 & 0.171 \\
& Yes & Yes & Yes & Yes \\
Predicted Default Probability & & & & \\
Banked Firms & 0.090 & 0.102 & 0.061 & 0.036 \\
\hline \hline
\end{tabular}

This table reports probit estimations of the probability of a banked firm getting approved for the credit program on a set of firm-level characteristics for the credit program eligible firms sample. The dependent variable is equal to one if the firm's loan application is approved and is zero otherwise. Columns 1, 2, 3, and 4 correspond to all banked firms, small firms, medium firms, and large firms, respectively. Risk corresponds to the fitted values of the regression specification reported in Table 1, Column 8. Increase (decrease) in sales dummy is equal to one if the firm experiences a positive (negative) variation in sales between February 2020 and April 2020 and is zero otherwise. Use employment program is a dummy variable equal to one for employment program participation and is zero otherwise. Standard errors, shown in parentheses, are clustered at the industry and municipality level. 
Table 8

Counterfactual Calculations of Aggregate Risk

\begin{tabular}{|c|c|c|}
\hline & & $\begin{array}{c}\text { Expected Loss / } \\
\text { GDP }(\%)\end{array}$ \\
\hline 1 & Baseline & 0.27 \\
\hline \multicolumn{3}{|c|}{ Equilibrium } \\
\hline 2 & No Low Default & 0.44 \\
\hline & No Credit Towards Safe Borrowers & 0.65 \\
\hline \multicolumn{3}{|c|}{ Policy } \\
\hline 4 & 100\% Guarantee and No Deductible & 0.77 \\
\hline 5 & $\begin{array}{l}\text { 100\% Guarantee and No Deductible } \\
\text { and Higher Amount Cap }\end{array}$ & 1.95 \\
\hline 6 & No Eligibility Constraints of Default & 0.69 \\
\hline
\end{tabular}

This table shows comparative statics of policy ingredients that potentially mitigate aggregate risk. Row 1 presents the baseline number from Table 6 . Row 2 presents aggregate risk in the case in which default rates are shifted upwards in a magnitude similar to how default rates increased during the 2008 global financial crisis (5 percentage point increase). Row 3 presents aggregate risk in the case in which all the credit allocated in the program goes to the riskiest firms. Row 4 presents aggregate risk when there is a complete guarantee and no deductible (and thus, all the allocation is driven by demand forces). Row 5 is the same as row 4 but allowing for a cap of 12 months (rather than the 3 months) of sales as credit. Row 6 presents the case in which there is no eligibility constraint on previous default behavior.

Table 9

Simulated Impacts of Policies Relative to Benchmark

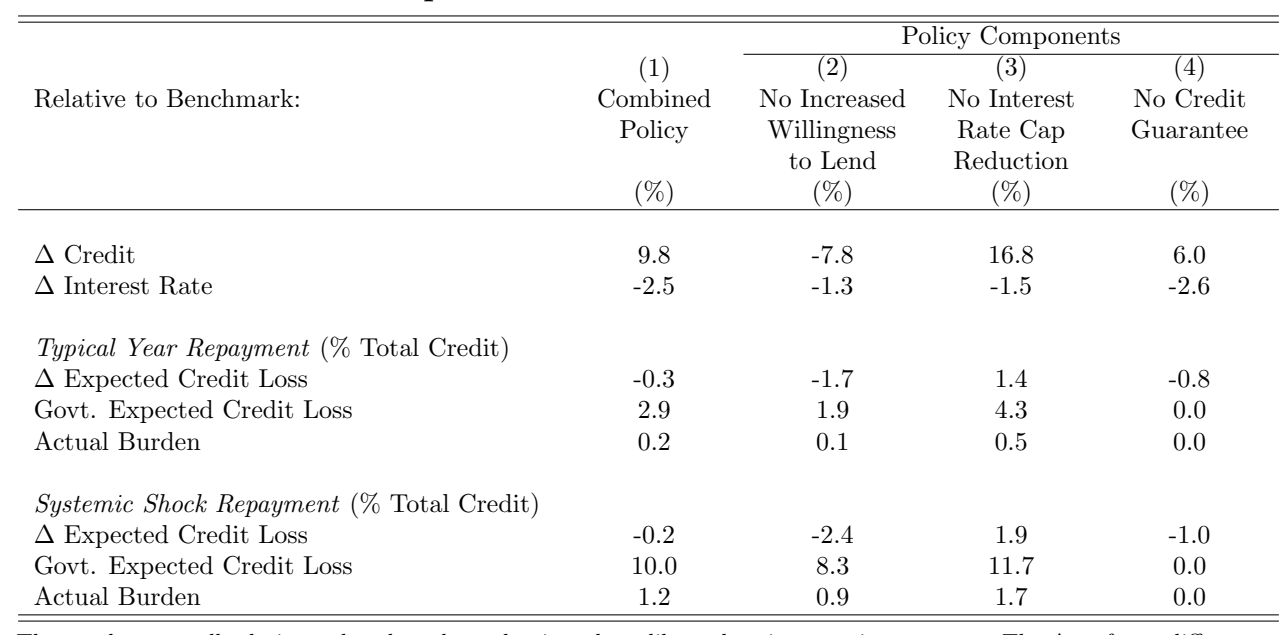

The numbers are all relative to benchmark results, i.e., the calibrated no-intervention economy. The $\Delta$ s refer to differences: policy simulation value minus benchmark simulation value. The benchmark results are the following: credit $=0.97$; interest rate $=4.0 \%$, "Expected Credit Loss" $=4.0 \%$ (typical year repayment); and "Expected Credit Loss" $=12.7 \%$ (systemic shock repayment). "Expected Credit Loss" is simply credit-weighted default. Since the government's share of expected credit loss ("Govt. Expected Credit Loss") and the government's actual burden ("Actual Burden") are zero in the benchmark - because there is no government guarantee - the values reported for both are the actual values. The government's share of expected credit loss is simply 0.8* "Expected Credit Loss" under policies with the guarantee rate of 0.8. However, the actual guarantee is only that fraction of losses. The actual burden is therefore less than this because of partial repayment of expected credit loss. Credit loss and actual burden are computed relative to total credit. 